\title{
The Supreme Court and the States: Reflections on Boynton v.Virginia
}

\author{
Louis H. Pollak*
}

$\mathrm{T}$ HE AMERICAN LAWYER'S well-advertised enthusiasm for taking even the flimsiest case "to the highest court in the land" is doubtless overdrawn. It is, nevertheless, true that the American bar-and the American people-have a long-standing penchant for constitutionalism, a penchant which was well developed when Tocqueville described it with clinical devotion more than a century ago. ${ }^{1}$ And a by-product of this phenomenon is the inescapable fact that very humble controversies have not infrequently reached the Supreme Court and provided the occasion for constitutional decisions of high consequence. It is especially noteworthy, and highly salutary, that the Supreme Court's revisory authority over the courts of the several states is not trammeled by jurisdictional limitations tied to the dollar value of a civil judgment or the severity of a criminal conviction. ${ }^{2}$

This was most dramatically illustrated at the Supreme Court's last term, when the Court, in Thompson v. Louisville, ${ }^{3}$ issued its writ of certiorari to the Louisville Police Court to review two $\$ 10$ fines imposed in a case too

* Associate Professor of Law, Yale Law School.

This essay takes as its point of departure a recent case, Boynton v. Virginia, 81 Sup. Ct. 182 (1960), which is treated in some depth. The reader is entitled to know that the writer was one of the lawyers who were "of counsel" to petitioner in the Supreme Court phase of the case. But this disclosure really only is relevant to the extent that it suggests the writer's bias. It would be incorrect to assume that this essay is simply an embroidering of the writer's contribution to petitioner's brief. In the first place, that contribution was minuscule. In the second place, the writer (as he now sees it) really didn't start thinking about Boynton v. Virginia until after the brief was written. A far more relevant disclosure is that, while Boynton was pending before the Court last fall, the writer assigned the case to a seminar he was conducting at Yale Law School; in the course of a month, members of the seminar briefed, argued, and "decided" the case. Unquestionably, therefore, many of the thoughts which follow were strongly influenced by the very challenging, and very discrepant, responses of the members of the seminar.

I "Scarcely any question arises in the United States which does not become, sooner or later, a subject of judicial debate; hence all parties are obliged to borrow the ideas, and even the language, usual in judicial proceedings, in their daily controversies." 1 TOcQuEvInte, DEMOCRACY IN AXIERICA 306 (4th ed. 1841).

2 Of course the Supreme Court's appellate jurisdiction in cases arising in the federal courts has no such qualifications, either. However, dollar minima are in fact built into most federal civil cases by the jurisdictional amount limitations which obtain at the district court level; but a significant exception is the body of higation, of which the School Segregation Cases, 347 U.S. 483 (1954), comprise a notable example, to restrain state interferences with the enjoyment of federal civil rights.

3362 U.S. 199 (1960). 
petty to fall within the appellate ambit of Kentucky's higher courts. The Supreme Court unanimously set aside a loitering and disorderly conduct conviction on the ground that the prosecutor had adduced "no evidence whatever") of Shufflin' Sam Thompson's guilt, and the Court thereby broke new constitutional ground. And the Court, speaking through Justice Black, took particular note of the case's modest beginnings: "[A]lthough the fines here are small, the due process questions presented are substantial ...."; and then the opinion recalled an earlier case in which, on fourteenth amendment grounds, the Court had set aside a $\$ 10$ police court fine-Yick Wo v. Hopkins. ${ }^{6}$

During its current term the Supreme Court reviewed still another $\$ 10$ police court conviction in Boynton $v$. Virginia. ${ }^{7}$ This time the offense charged was trespass, and grew out of the refusal of a homeward-bound Negro law student to eat in the "colored" portion of a Richmond bus terminal restaurant. In the Supreme Court Bruce Boynton ultimately prevailed, $^{8}$ as Sam Thompson and Yick Wo had before him. But Boynton's victory was not pitched on fourteenth amendment grounds-indeed, he did not win on constitutional grounds at all, but only on the humdrum ground that his conviction contravened a governing federal statute. In all likelihood, therefore, Boynton's case will soon slip into relative obscurity.

But before this happens, Boynton v. Virginia is worth examining with some care. As it was argued to the Court, Boynton seemed, in one sense, larger than Thompson and larger even than Yick Wo. For it was, in microcosm, a case embodying the full spectrum of the Court's revisory authority over the states. At its outer limits, the case presented the fourteenth amendment problems latent in the 1960 "sit in" demonstrations conducted throughout the South by students protesting the refusal of public eating places to cater to Negro patrons. Less broadly conceived, the case still raised searching questions as to whether racial segregation in bus terminal restaurants constituted an inadmissible burden on interstate commerce. And at the core of the case lay a difficult issue as to the possible relevance of the Interstate Commerce Act, ${ }^{9}$ an issue which had been half-heartedly

$4 I d$. at 206.

5 Id. at 203.

6118 U.S. 356 (1885). Actually the Yick Wo opinion decided two consolidated cases: Yick Wo v. Hopkins and Wo Lee v. Hopkins. Justice Matthews' statement of the cases makes it clear that Yick Wo was fined $\$ 10$, and then sentenced to jail at the rate of a dollar per day to work off the unpaid fine. It is unclear whether Wo Lee's case, which Justice Matthews termed "precisely similar" but which reached the Supreme Court through a different procedural path (federal rather than state habeas corpus), involved the same penaltics.

781 Sup. Ct. 182 (1960).

8 Ibid.

949 Stat. 543 (1935), 49 U.S.C. ch. 8 (1958). 
tendered, and then apparently abandoned, below, but which the Court itself, in a rather unusual fashion, resuscitated and then found dispositive.

Such a multiplicity of issues is not, of course, unprecedented. But now that substantive due process has become an almost negligible limitation on state economic regulation, there seem to be fewer and fewer litigated matters in which a single transaction gives rise to difficult issues ranging across the constitutional board. ${ }^{10}$ When such a many-faceted case does arise, the Court is not tied to the gross choice of voting petitioner up or down on a single dominant constitutional claim. The Court may find itself free to choose among two or three approaches in resolving, for the purposes of that case, the endlessiy besetting conundrum of the American federal systemthe accommodation, in ceaselessly shifting contexts, of national, state, and individual demands. ${ }^{11}$ Judicial authority to select the most apt of several possible avenues of decision is a sensitive and a powerful weapon. Utilized with sophistication, it complements the Supreme Court's broad discretion as to which cases the Court will entertain, and in what sequence. It is a weapon which strengthens the wielder, but which tests him as well.

On December 20,1958, thousands of American students were heading home for the Christmas holidays. At eight o'clock that evening Bruce Boynton, a senior at Howard Law School, left Washington on a Trailways bus (evidently operated by Virginia Stage Lines, a constituent part of the Trailways system) bound for Montgomery; Boynton's destination was his home in Selma, Alabama. Some two and a half hours later the bus made a forty minute stop at the Trailways Bus Terminal in Riclmond. Boynton was hungry; a stranger in town, and in something of a liurry, he wandered into the nearest restaurant-a restaurant located in the bus terminal building -for a quick meal. The restaurant, a tenant of the terminal, was a segregated establislment, one section reserved for white patrons, the other for Negroes.

Boynton might have acquiesced in this arrangement. He might have ruminated upon the fact that in a brief evening's ride he had peacefully traversed the bloody ground which had separated the Union and Confederate capitals-ground which it had taken Lincoln's armies four years to win. He might even have smiled, perhaps a little ruefully, at the thought that the next day his Trailways bus would deposit him, safe and sound, in the "Cradle of the Confederacy." And the rumination and the rueful smile might have worked their chemistry on Boynton, as lie entered that Jim

10 But cf., e.g., Toomer v. Witsell, 334 U.S. 385 (1948).

11 of course the Court may examine several proferred grounds of reversal and find them all wanting. See, e.g., Breard v. Alexandria, 341 U.S. 622 (1951). 
Crow restaurant in Richmond, and might have tempered his human anger with the more-than-human patience with which most American Negroes have for so long, perhaps too long, adapted themselves to white oppression. Thus fortified and disarmed, Boynton might have been able to regard his bus trip home as a sort of decompression chamber headed back into history - a reverse time capsule temporarily transporting him from mid-20th century Washington (a city which only today is earning entitlement to be the capital of the American democracy) ${ }^{12}$ back, via easy "separate but equal" stages, to the obsolescent "whites-only"-isn of the deep, deep South.

But Boynton didn't acquiesce. He sat down at the counter in the white section of the restaurant. What then happened is best told in his own later testimony:

[A]t the time that I sat down the waitress-one of the waitresses on duty came up to me and asked me to go over on the other side, that they had facilities over there. I told the waitress that the facihties over there were a bit crowded, and also that I was an interstate passenger and that I could eat there at that restaurant. She told me that she had orders and it was customary not to serve me.

Whereupon I explained to her again that I was an interstate passenger and that I had a bus to catch in about thirty minutes, thirty or forty minutes, and that I would like something that wouldn't take too long to prepare. Whereupon she suggested that I purchase a prepared sandwich, sandwich that was already made. I believe they had some several lined up to the counter there. So I ordered one of the sandwiches and tea with cream. She didn't write the order, but she went away and then came back and said that she couldn't serve me, she had orders not to serve me. Whereupon, I asked her to get someone who could since she had orders not to and that I was an interstate passenger. She went away and Mr. Rush [the assistant manager] here appeared and told me that I couldn't be served and suggested that I go over on the other side.

At that time I pulled out my ticket, showed it to him, explained what that passenger was, and he asked me to move. He made a demand for me to move and I refused.

He went away and I sat there. The next thing that happened was that Officer 198 appeared and told me that I was under arrest. I explained to him that I was an interstate passenger also and he conferred, I believe, with Officer 66 , who I later went into the custody of this officer, and they wrote out a warrant and I proceeded on the bus in the custody of Officer 198 and took my things off and disembarked from the bus. ${ }^{18}$

Boynton was arrested on a charge of trespass, under a Virginia statute which makes it a misdemeanor, punishable by up to thirty days in jail and

12 See Bolling v. Sharpe, 347 U.S. 497 (1954) ; District of Columbia v. Thompson Co., 346 U.S. 100 (1953) ; Hurd v. Hodge, 334 U.S. 24 (1948). The citations relate, of course, only to the advances made through litigation.

18 Transcript of Record, pp. 28-29, Boynton v. Virginia, 81 Sup. Ct. 182 (1960). 
a $\$ 100$ fine, "without authority of law ... [to] remain upon the lands or premises of another after having been forbidden to do so by the ... lessee, custodian, or person lawfully im charge of such land. . . ."14 Initially, the warrant against Boynton alleged that he had trespassed "upon the premises at Trailways Bus Terminal. . . .15 Later, this was amended to charge that Boynton "unlawfully did remain on the premises of the Bus Terminal Restaurant of Richmond, Inc. . . ." The case came on for trial on January 6, 1959, before Hon. Harold C. Maurice, Judge of the Richmond Police Court. After hearing nineteen minutes of testimony from the restaurant's assistant manager, the arresting officer, and the defendant, Judge Maurice found the defendant guilty. The Judge filed no opinion, but his judgment- "Fined $\$ 10.00 \& \$ 6.25$ costs"-was duly entered on the jacket of the arrest warrant. ${ }^{17}$ The jacket caption misspelled Boynton's name and his home town; but it did accurately record the important biographical information - "CM 21"18 - a notation which seems to mean, under Virginia law, that the defendant was a colored male, age twenty-one.

Boynton appealed to the Hustings Court of Richmond, alleging that his conviction infringed his rights under the Interstate Commerce Act, the commerce clause of the Constitution, and the fourteenth amendment. That court, on March 6, 1959, adhered, without opinion, to the lower court's verdict and sentence. Three months later, the Virginia Supreme Court of Appeals refused a writ of error to review the action of the Hustings Court, "Being of opinion that the said judgment is plainly right. . .." 18

On September 15, 1959, Boynton filed a petition for certiorari in the United States Supreme Court.

The petition raised two constitutional questions of far-reaching implication.

The first question was whether segregation of interstate passengers in a dining facility which is an integral part of a system of interstate transportation constitutes a "burden" on interstate commerce in the same sense that racially segregated seating of passengers on interstate buses was found, in 1946 , in Morgan v. Virginia, ${ }^{20}$ to be an impermissible local impediment to free interstate travel. Subsumed under this question was the problem whether a burden on commerce is vulnerable to judicial attack if it is merely the product of private policy-such as the racial policy of the terminal restaurant-or whether the Court's power to strike down burdens on commerce comes into play only where the burden is imposed by an affirmative

14 VA. Code ANN. § 18-225 (1950) (now § 18.1-173 (1960)).

15 Transcript of Record, p. 1, Boynton v. Virginia, 81 Sup. Ct. 182 (1960).

16 Ibid.

17 Id. at 2.

18 Ibid.

$10 \mathrm{Id}$. at 32 .

20328 U.S. 373 (1946). 
state mandate, such as the Virginia statute requiring segregated seating invalidated in Morgan. The possibility that private obstructions to commerce might be the subject of judicial attack has clouded the doctrinal air ever since In re Debs, ${ }^{21}$ in which the Court exercised and indeed described its powers with a grandiloquence never since matched and seldom thereafter admired-but never flatly repudiated. However, on the assumption that only state-imposed burdens are amenable to judicial scrutiny, there was in Boynton the further question whether Virginia's use of its trespass statute to enforce the private racial policy of the restaurant was sufficient state intervention to bring the commerce clause into play.

The second constitutional question was whether state enforcement of the restaurant's segregation policy denied Boynton the equal protection of the laws. Since the fourteenth amendment concededly speaks only to "state action," it was, of course, plain that under this aspect of the case no constitutional question was presented unless the challenged differential treatment was not only an unjustified discrimination, but was a discrimination which was in some fashion attributable to the Commonwealth. Had Boynton involved a state statute requiring segregated seating in restaurants, the statute's invalidity would have been pretty clear. The School Segregation Cases $^{22}$ themselves looked strongly in this direction; and subsequent per curiam decisions invalidating state statutes requiring segregation in parks, beaches, golf courses, theaters, and intrastate buses would seem, cumulatively, to be controlling authority. ${ }^{23}$ But Boynton did not involve a racial statute. It involved a conventional trespass statute, which left the formulation of racial policy up to the particular property owner or tenant. Therefore, Boynton raised a new and more difficult question: Whether the fourteenth amendment inhibits state enforcement of an entirely neutral statute, when such enforcement puts the muscle of law behind the discriminatory business practices voluntarily adopted by a private entrepreneur.

In brief compass, these were the very substantial commerce and equal protection issues implicit in Boynton's certiorari petition. Boynton's petition contaimed no mention of the more modest claim, mentioned in passing

21158 U.S. 564 (1895).

22 Brown v. Board of Education, 347 U.S. 483 (1954).

23 New Orleans City Park Improvement Ass'n v. Detiege, 358 U.S. 54 (1958) ; Mayor \& City Council of Baltimore v. Dawson, 350 U.S. 877 (1955); Holmes v. City of Atlanta, 350 U.S. 879 (1955) ; Muir v. Louisville Park Theatrical Ass'n, 347 U.S. 971 (1954) ; Gayle v. Browder, 352 U.S. 903 (1956). Possibly, as has been argued by Professor Brown [Brown, Foreword: Process of Law, The Supreme Court, 1957 Term, 72 HARv. L. REv. 77 (1958)] and Professor Wechsler [Wechsler, Toward Neutral Principles of Constitutional Law, 73 HARv. L. REv. 1, 22 (1959)], these issues should not have been disposed of via the per curiam route. But they have been so disposed of; and, looked at en masse, they seem collectively to stand for the general principle that publicly ordained racial segregation is inconsistent with the demands of the equal protection clause. But see footnote 79 infra. 
in the Hustings Court, that the Interstate Commerce Act barred Virginia's enforcement of the terminal restaurant's preference for segregation. At the certiorari stage, this pre-emption issue seemed to have dropped out of the case.

\section{II}

Under the Supreme Court's rules, Virginia had thirty days in which to file a brief in opposition to Boynton's petition for certiorari; but the allotted time passed without any word from the Commonwealth. Had the Supreme Court been so minded, it could, of course, have decided then and there whether or not to entertain the case on its nerits. But, quite understandably, the Court was reluctant to enter Boynton's constitutional thicket on the basis of his unilateral submission. And so, after nearly two more nionths had elapsed, the Court directed that a letter be dispatched to Richmond:

Honorable A. S. Harrison, Jr.

December 12, 1959

Attorney General of Virginia

Richmond, Virginia

Re: Boynton v. Virginia

No. 409, October Term, 1959

Dear Sir:

On instructions from this Court, I am writing to ask if the Commonwealth of Virginia will be good enough to respond to the petition in the above case and, included in its response, deal with the intercorporate relationship between the Trailways Bus Company and the Trailways Bus Terminal, Inc., set forth in any documents of which the Virginia courts can take judicial notice. Compare Henderson v. United States, 339 U.S. 816.

It is further requested that you set forth your view of the controlling Virginia law under which, it is claimed, petitioner was convicted for trespass.

$$
\begin{aligned}
& \text { Very truly yours, } \\
& \text { James R. Browning, Clerk } \\
& \text { By /s/ R. J. Blanchard } \\
& \text { R. J. Blanchard } \\
& \text { Deputy }{ }^{24}
\end{aligned}
$$

The letter is notable on several levels. The devotee of business Enghish may be intrigued by the form of the request: If one is supreme enough, one writes "to ask if [a sovereign state] will be good enough to respond" to an adversary in the same way that a humbler mortal asks his dinner companion if she will be good enough to pass the salt. For the practicing lawyer, the letter illustrates the somewhat surprising fact that the Suprenie Court occasionally communicates with one litigant, on matters of substance, without

24 Brief for Respondent in Opposition to Petition for Certiorari, p. 12, Boynton v. Virginia, 81 S. Ct. 182 (1960. 
notice to his adversary. And the student of constitutional adjudication may be interested in the initiative taken by the Court to shift the focus of a case to an issue not embraced within the "questions presented" by petitioner. That this was the Court's purpose is evident from the letter's reference to Henderson $v$. United States, ${ }^{25}$ coupled with the Court's question about "the intercorporate relationship between the Trailways Bus Company and the Trailways Bus Terminal, Inc....." The Court was attempting to probe the issue which petitioner had raised in the Hustings Court but had not pursued - the possible relevance of the Interstate Commerce Act. The Supreme Court's question seems modest enough, but it will require some rather roundabout explication to suggest the course of thinking which inust have prompted the judicial question.

Henderson was a case challenging the Southern Railway's practice of partitioning off, for exclusive Negro use, one table in each dining car, and its corollary practice of refusing to serve Negro passengers at vacant seats elsewhere in the car. These arrangements were held by the Court to violate section 3(1) of the Interstate Commerce Act:

It shall be unlawful for any common carrier subject to the provisions of this part ... to make, give, or cause any undue or unreasonable preference or advantage to any particular person, company, firm, corporation, association, locality, port, port district, gateway, transit point, region, district, territory, or any particular description of traffic, in any respect whatsoever; or to subject any particular person, company, firm, corporation, association, locality, port, port district, gateway, transit point, region, district, territory, or any particular description of traffic to any undue or unreasonable prejudice or disadvantage in any respect whatsoever: . . . ${ }^{26}$

But Elmer Henderson was a rail passenger, while Bruce Boynton was travelling by bus. To test the relevance of the Henderson rule to Boynton's problem, one must thumb through the Interstate Commerce Act to title II, which deals with notor carriers. And there, sure enough, one finds language closely approximating section 3(1). According to section 216(d):

It shall be unlawful for any common carrier by motor vehicle engaged in interstate or foreign commerce to make, give, or cause any undue or unreasonable preference or advantage to any particular person, port, gateway, locality, region, district, or description of traffic, in any respect whatsoever; or to subject any particular person, port, gateway, locality, region, district, territory, or description of traffic, to any unjust discrimination or any undue or unreasonable prejudice or disadvantage in any respect whatsoever ....27

This statutory language, buttressed by the decision in Henderson, would seem compelling, indeed, if Boynton's troubles had arisen while he was

2749 Stat. 558 (1935), 49 U.S.C. $\$ 316$ (d) (1958). 
aboard the bus, or on other premises administered by the motor carrier. Then, if the Interstate Commerce Act were accorded the full pre-emptive effect to which it is entitled as one facet of "the supreme law of the land," Boynton would have had a clear defense to Virginia's trespass action; more than that, he probably could have enjoined the carrier from maintaining the obnoxious policy in the future, and he might have recovered danrages for the indignities visited upon him. ${ }^{28}$ But, superficially at least, this was

28 "The possible double aspect of the cause of action, for future relief from the discriminatory practice in general, and for damages for the act of discrimination in particular, was recognized in Mitchell v. United States, 313 U.S. 80 . . ." Lyons v. Mlinois Greyhound Limes, 192 F.2d 533, 534 (7th Cir. 1951). Notwithstanding the Seventh Circuit's confident pronouncement, there remains some question as to the source of the "cause of action" (at least insofar as it contemplates a recovery in damages) and as to the appropriate tribunal. It has been said that the recovery of money damages depends on the existence of such a right under the "local" law. See Fitzgerald v. Pan American World Airways, 132 F. Supp. 798, 801 (S.D.N.Y. 1955), rev'd, 229 F.2d 499 (1956). Yet the absurdity of determining the "Iocal" law (in Boynton, would it be Virginia tort law, or perhaps District of Columbia contract law?) governing an hiterstate carrier, and of making a federal court defer to a state court's choice of that law (see Klaxon v. Stentor, 313 U.S. 487 (1941)) argues strongly that a right to recover damages for violating a federal statutory obligation not to discriminate should be as much a matter of uniform federal policy as the underlying nondiscrimination standard. Yet to say this does not hevitably compel the conclusion that only the federal courts can entertain a suit for daniages based upon federal law. Concurrent jurisdiction over federal causes of action of a common-law flavor is certainly an established and generally salutary characteristic of the distribution of judicial tasks within the federal system. Conversely, the Second Circuit's recent intimation that the ICC's authority to order reparations gives that agency "exclusive primary jurisdiction" over damage actions (see Fitzgerald v. Pan American Airways, 229 F.2d 499, 502 (1956)) seems an inappropriate attempt to equate the trial of issues which are the staple fare of judges and juries with the trial of those economic issues arising out of shipper-carrier controversies which are the routine first instance business of the presumptively expert ICC.

It is a fair guess that both issues-the source of the cause of action, and the proper tribunal -will be lotly disputed in a law suit just filed in a New York federal court against "Safeway Trails, Inc., operators of Trailways Buses," which is reported by The New York Post, Jan. 31, 1961, p. 22, in the following terms:

\section{Sues Bus Line in Jin Crow Incident}

A $\$ 125,000$ damage claim has been brought against the operators of Trailways Buses by a Brooklyn woman who alleges that she was dragged from an interstate bus in Warrenton, Ga., and severely beaten by a police officer who demanded that she move to the rear of the vehicle.

In her suit, filed in Federal Court here, Mrs. Florence Blaize Ephraim, 39, of 799A Monroe St., charges that the company failed to safeguard lier riglits.

According to Mrs. Ephraim, who is a Negro and a registered nurse, the incident occured [sic] Aug. 6, 1959, while she was on a bus bound for Montgomery, Ala.

Mrs. Ephraim, wlio was born in Grenade, West Indies, said she had dozed off when she was awakend by the policeman and ordered to move to the rear of the bus. The bus bad come to a halt.

Refused to Move

"I was tired and I refused to nove," Mrs. Ephraim said. "I turned to look for the bus driver, but he was nowliere in sight. Then the man grabbed me and insisted that I move, so I said, "Just a minute."

"I bent down to pick up my shoes and pocketbook and the next thing I knew I was being dragged off the bus. As I stumbled down the steps I suddenly received a blow in the liead which dazed me. When I came to my senses, I found myself 
not Boynton's situation. The racial segregation which he resisted, to the point of arrest, was practiced by the bus terminal restaurant-the lessee of the terminal's corporate owner-not by the carrier. Accordingly, section 216(d) of the Interstate Commerce Act, relating to buses, would not seem to afford Boynton the protection which its railway counterpart, section $3(1)$, had afforded Henderson. Such would seem to be the conclusion, that is, unless the gap in Boynton's case-the identification of the restaurant with the carrier-could be bridged by the comprehensive language of section 203 (a) (19) of the Interstate Commerce Act, another of the provisions dealing with motor carriers:

The "services" and "transportation" to which this part ... . applies include all vehicles operated by, for, or in the interest of any motor carrier irrespective of ownership or of contract, express or implied, together with all facitities and property operated or controlled by any such carrier or carriers and used in the transportation of passengers or property in interstate or foreign commerce or in the performance of any service in connection therewith. ${ }^{20}$

Armed with this provision, could not one reasonably conclude that the feeding of interstate bus passengers in a bus terminal is a "service in connection with" the interstate transportation of such passengers, and that the racially segregated administration of the "facilities and property . . . used ... in the performance of [such] service" would be "unjust discrimination or ... undue or unreasonable prejudice" within the meaning of section 216(d)? Yes, of course-if the "facilities and property" in question fell within the class described by Congress: "facilities and property operated or controlled by any such carrier. ..."

But, unfortunately for Boynton's case, the record made at his trial seemed flatly to foreclose a finding that the carrier "operated or controlled" the restaurant. The issue had been probed at the very outset of the trial. The attorney who put the relevant questions was counsel for the restaurant, a lawyer who had advised Police Court Judge Maurice that he was "appearing with the Commonwealth's Attorney" ${ }^{30}$ and who thereafter extended his

sprawled on a bench near the bus with my head on the ground and my legs in the air.

"I tried to stagger back to the bus, but the policeman hit me across the legs and said, 'you goddamn miggers listen to what the Supreme Court tells you to do but when you're in Georgia every white man and white woman is your master.'"

As a result of the beating, she said, the sight in her right eye has been impaired and she continues to suffer from dizzy spells.

Safeway Trails, Inc., operators of Trailways Buses, have 20 days in which to answer her suit.

2949 Stat. 545 (1935), 49 U.S.C. $\$ 303$ (a) (19) (1953).

30 Transcript of Record, p. 19, Boynton v. Virginia, 81 Sup. Ct. 182 (1960). The restaurant's stake in the outcome of the case becomes clear on examination of the Boynton opinion, since 
courtesy to the point of conducting the entire trial on the Coinmonwealth's behalf. The first witness called by the restaurant's lawyer was the assistant manager of the restaurant, and he testified with the assurance that can only come from years of bearing the naine Stanley Sylvanius Rush:

Q. The company that operates the restaurant is not affiliated in any way with the bus company, is it?

A. No, sir, it is not.

Q. The bus company has no control over the operation of the restaurant?

A. None whatsoever. ${ }^{31}$

Boynton's counsel did not seek to shake Mr. Rush's testimony on crossexamination. And neither the police officer nor Boynton spoke to the point. The only other evidence in the record that shed light on the management of the restaurant was the five-year contract of lease between the terminal company and the restaurant which was in force on the date of Boynton's arrest. The lease articulated at some length the joint determination of the parties to maintain a "restaurant [and newsstands] in keeping with the character of service maintained in an up-to-date, modern bus terminal."32 Under the lease, the terminal company apparently retained substantial authority to scrutinize and require changes in the restaurant's mode of operation. But nothing in the lease intinated that any authority over the restaurant was to be exercised by any carrier utilizing the terminal.

Nothing, that is, except the curious similarity of the lessor's nameTrailways Bus Terminal, Inc.- to the name of the bus system on which Boynton was travelling when his trip was so rudely interrupted. If, by some chance, the verbal similarity was not mere coincidence-if, for example, the terminal corporation happened to be an alter ego of the bus systemthen perhaps one could breathe new life into a statutory argument on Boynton's behalf. For then there might be some substance in the notion that the restaurant facilities were "controlled" by the "carrier," in the sense intended by section 203(a) (19), and hence could not be administered in such a fashion as "to subject ... [Boynton] to any unjust discrimination or any undue or unreasonable prejudice," within the meaning of section $216(d)$.

Such an analysis, if supportable in fact, held out to the Supreme Court the possibility of setting aside Boynton's conviction without reaching con-

the Court held that in circumstances like those presented in Boynton, "the terminal and restaurant stand in the place of the bus company in the performance of its transportation obligations." 81 Sup. Ct. at 186. This holding raises real possibilities that the restaurant, like the carrier, might be liable in damages for its discriminatory activities. See note 28 supra.

31 Id. at 20.

32 Id. at 14 . 
stitutional issues of great dimension. ${ }^{33}$ Of course, petitioner had elected to bring only the constitutional issues to the Supreme Court's attention. But the Court cannot-and should not-be forced to conform to the mold in which a petitioner shapes his case; the Court must be free to postpone the adjudication of constitutional issues when lesser issues can be dispositive. This is even so, as Chief Justice Warren made dramatically clear in Peters v. $H o b b y,{ }^{34}$ when both litigants argue that a less than constitutional solution is beyond judicial reach. Thus, in Boynton, it was entirely consistent with the Supreme Court's highest traditions and responsibilities for that tribunal to seek to revive a statutory contention which petitioner had left at the threshold of the Hustings Court. One can conjecture, therefore, that it was this circuitous path-pursued, possibly, in the reverse directionwhich led the Court, in its letter to Attorney General Harrison, to ask the Commonwealth to "deal with the intercorporate relationship between the Trailways Bus Company and the Trailways Bus Terminal, Inc. ...."

The one difficulty with the Court's inquiry was that the record before it was totally devoid of any evidence demonstrating the existence of an "intercorporate relationship." Wherefore the Court qualified its request; the Court sought enlightenment on any "intercorporate relationship ... set forth in any documents of which the Virginia courts can take judicial notice."

Not too surprisingly, the Commonwealth of Virginia thereafter filed a response to Boynton's petition. And, not too surprisingly, the Commonwealth found no documents bearing on the "intercorporate relationship" which the courts of Virginia could judicially notice. But, somewhat more surprisingly, the Supreme Court, on February 23, 1960, granted certiorari. ${ }^{35}$ Perhaps some of the Justices felt up to tackling one of the constitutional issues. Or perhaps some of the Justices, notwithstanding the apparent implication of their own letter, were not fully persuaded that a state's doctrines of judicial notice should foreclose the Supreme Court from ascertaining those public facts which may be essential to the full exercise of the Court's authority to review state court adjudications of claims arising under federal law. All that can be said with confidence is that at least four members of the Court wanted to get a closer look at the case.

33 The Supreme Court could, of course, have denied Boynton's petition for certiorari. But the Justices may well have sensed that an unreversed criminal conviction, for even so negligible an offense and with so slight a penalty, might pose special problems for a would-be lawyer. At all events, after certiorari was granted, the Court was advised that the Virginia prosecution had apparently interfered with petitioner's admission to the Alabana bar. See Brief for Petitioner, p. 5 n.2, Boynton v. Virginia, 81 Sup. Ct. 182 (1960).

34349 U.S. 331 (1955).

35361 U.S. 958 (1960). 
III

The Court's interest in the possible "intercorporate relationship" of the carrier and the terminal came to liglit when the Commonwealth printed the Clerk's letter as an appendix to its response to the certiorari petition. Since, in the Commonwealth's view, the astrimgent character of Virgima's law of judicial notice made a search for the requested information academic, petitioner's lawyers undertook to determine for themselves whether there were any public records which miglit have bearing on the issue broached by the Court. In the files of the Virginia Corporation Commission were found certain corporate charters and annual corporate reports which seemed relevant. These documents, certified copies of which petitioner's lawyers deposited with the Clerk of the Supreme Court, were said to demonstrate that "the terminal in question is owned by Trailways Bus Terminal, Inc., whose officers and directors, in 1959, with one exception, were all also officers or directors of either Carolina Coach Company or Virginia Stage Limes. .. ."36 And then the United States, which liad asked and been granted permission to file a brief as amicus curiae, came forward with further information; according to a required Annual Report on Orgamization and Control filed by Virginia Stage Lines with the Interstate Commerce Commission, Virgima Stage Lines acknowledged that it was "doing business as Virginia Trailways," and that it owned " $50 \%$ stock of Trailways Bus Terminal, Inc. which is operated as a joint Terminal facility in Richmond, Virgima with Carolina Coach Company." Moreover, the carrier histed "Trailways Bus Terminal, Inc., Richmond, Va." as one of fifteen terminals, maintenance firms, and other carriers which it "controlled . . . directly or indirectly."37

As Virginia Stage Lines, according to its own statement, "controlled" the terminal, so too it presumably controlled the disposition of the terminal's premises-and, specifically, controlled the substance and the terms of the business decision to rent a portion of those premises for restaurant purposes. The carrier would appear, in effect, to have been the lessor, and hence a full participant in the joint undertaking, described in the lease, to create and maintain a "restaurant . . . in keeping with the character of service maintained in an up-to-date, modern bus terminal." If the "service" thus provided turned out to be of a racially discriminatory character, the carrier's apparent partnership in the maintenance of that service could very plausibly be said to constitute a violation by the carrier of the injunction contained in section 216(d) of the Interstate Cominerce Act against "unjust discrimination or ... undue or unreasonable prejudice . . . in any re-

${ }^{36}$ Brief for Petitioner, p. 22, Boynton v. Virginia, 81 Sup. Ct. 182 (1960).

37 Brief for the United States as Amicus Curiae, pp.30-31, Boynton v. Virginia, 81 Sup. Ct. 182 (1960). 
spect whatsoever," in this instance, in respect to facilities of a kind precisely described in section 203(a) (19) of the Act-_"facilities . . . controlled by any ... carrier, and used in the transportation of passengers ... in interstate ... commerce or in the performance of any service in connection therewith."

In sum, the Court would have been on reasonably defensible ground had it found (1) that the "intercorporate relationship" of this carrier and this terminal was such as to make the Interstate Commerce Act applicable to a lessee of the terminal which furnished service to interstate passengers, and (2) that the Act in turn proscribed the racially differentiated treatment which lay at the root of Boynton's trespass conviction. The relevant facts of corporate life, whose existence the Court had very sensibly suspected, appeared to provide an adequate means of disposing of the case-a means which was at once faithful to the Court's lawyerly skills and harmonious with its judicial responsibility to eschew gratuitous constitutional decisions.

All appeared ready for such a denouement. The corporate facts had apparently been validated-indeed they were, quite naturally, undisputed. Only two small problems remained:

A. Neither petitioner nor the United States took issue with the Commonwealth's assertion that the courts of Virginia could not judicially notice the facts. On this issue, there appeared to be no decisive authority one way or another ${ }^{38}$ Under such circumstances, a state attorney general's assessment of his own state's law is ordinarily, and very properly, given very great weight by the Supreme Court. ${ }^{39}$

B. Whatever Virginia's law of judicial notice might be, this issue had significance only to the extent that the Supreme Court indulged the supposition, imphicit in its Clerk's letter, that its power to notice relevant and undisputed public facts might depend on whether the courts of Virginia

38 Section 8-272 of the Virginia Code provides for the receipt in evidence of reports filed with the Virginia Corporation Commission or the ICC, and it is certainly arguable that reports not introduced at trial, pursuant to this statutory authority, should not be received on appeal via the judicial notice route. Cf. Commonwealth v. Castner, Curran \& Bullit, 138 Va. 81, 121 S.E. 894 (1924) ; Stevens v. Mirakian, 177 Va. 123, 12 S.E.2d 780 (1941). On the other hand, the Virginia Court of Appeals has found it possible to inform itself of natters bearing on the operations of interstate carriers which have not been proved below. See Morgan v. Pennsylvania R.R., 148 Va. 272, 138 S.E. 566, 568 (1927): "This court will take judicial notice of the fact that the defendant [Pennsylvania Railroad] operates a railroad, as a common carrier, in the state of Virginia, upon tracks extending through Accomac and Northampton counties, and thence from Cape Charles, in Northampton county, upon a barge ferry into the city of Norfolk, where it owns property and conducts its business as such carrier." Cf. Fleming v. Comnonwealth, 191 Va. 288, 61 S.E.2d 1, 3-5 (1950).

39 In Boynton, the attorney who, as "special assistant" to the Virginia Attorney General, argued the cause for Virginia in the Supreme Court, was the attorney who, as counsel for the restaurant, had in effect conducted Boynton's prosecution in the Richmond Police Court. See note 30 supra. 
had such power. In some past instances, to be sure, "The Federal Supreme Court... on the scholastic theory that it cannot know on appeal what the Court below could not know, has declined, on writ of error to a State Supreme Court, to notice what the latter could not notice. .. ."40 But, without bothering to formulate any very elaborate rationalization of the process, the Court has recently seemed to find ways of acquainting itself with public information without binding itself meticulously to the record made in the state courts. ${ }^{41}$ In Boynton, it seemed reasonable to anticipate that the Court

409 WIGMORE, EvIDENCE 556-57 n.9 (3d ed. 1940). In his dissenting opinion in Boynton, Justice Whittaker cited Lawn v. United States, 355 U.S. 339, 354 (1957) and Wolfe v. North Carolina, 364 U.S. 177 (1960) to support his conclusion that, if the public documents outlining the connection between the carrier and the terminal were not open to scrutiny in a Virginia appellate court, "the proferred documents cannot be considered here." 81 Sup. Ct. at 189-90 n.5. Lawn has no bearing on Boynton: it was a federal criminal prosecution in which the court declined to let the Government go outside the trial record to show the harmlessness of an error which, so the Court leld, petitioner had in any event waived objection to. Wolfe, at first blush, sounds like a case which may have relevant things to say about the relation of the Supreme Court to state courts. But, on analysis, Wolfe also seems to be directed to a different problens: In Wolfe, the defendants in a North Carolina trespass prosecution were Negroes charged with playing golf on a privately operated golf course after being told to stay off. The defendants sought to introduce at the state trial the findings made in a prior civil proceeding in the North Carolina federal district court in which they and other Negroes bad been plaintiffs. In that federal proceeding the district judge (1) had held that the golf course, which was located on leased mumicipal land, was a public facility; (2) had found that Negroes had on a number of occasions been excluded on racial grounds; and (3) had enjomed continued racial exclusion. The state trial judge excluded the federal court findings, and instructed the jury that it could find the defendants guilty if satisfied that they were not barred because of their race. The jury found defendants guilty. On appeal, defendants argued that the federal court findings showed that this very alleged trespass was an instance of racial exclusion, and bence that federal collateral estoppel foreclosed the state prosecution. However, defendants failed to include in the state record on appeal the portion of the trial transcript which showed the rejection of the federal court findings. The North Carolina Supreme Court therefore treated the case as if no offer of the federal court findings had been nuade, and thereby avoided appellant's federal claim of collateral estoppel. In the United States Supreme Court a majority of five concluded that appellants' failure to assemble a record which, under the North Carolina practice, demonstrated the existence of the federal question, justified the state supreme court's refusal to entertain that federal question. And, in the majority's view, the state court's judgment of affirmance therefore rested on an adequate independent state ground, which meant in turn that the appeal to the United States Supreme Court had to be dismissed.

Thus, the holding in Wolfe was relevant to Boynton only in that it tended to support the very different proposition (which Justice Whittaker also advanced, in reliance on Laven but not on Wolfe) that Boynton's trial court reliance on the Interstate Commerce Act had been abandoned in the Virginia appellate courts and hence was unavailable in the United States Supreme Court. But, once the Boynton majority passed that jurisdictional issue, nothing in Wolfe compelled the conclusion that the Supreme Court could not notice facts which a state supreme court, under its own judicial notice doctrines, might have declined to notice.

41 In Fay v. New York, 332 U.S. 261 (1947), both the majority (id. at $275 \mathrm{n} .15$ ) and the dissenting Justices (id. at 298) considered a statistical table prepared by the Bureau of Labor Statistics, at petitioner's instance, although it was "not put ni evidence" in the state courts (id. at 275) and was characterized by the state as not constituting "the type of evidence required of one seeking to invalidate a state conviction on federal grounds...." Brief for Respondent, p. 16, 
would be willing to examine documents filed with the Virginia Corporation Commission and the Interstate Commerce Commission-documents whose authenticity and accuracy had at no point been challenged-without regard for the fact that defense counsel had not tracked the documents down as part of his routine preparation for trial in the Richmond Police Court or for review of the $\$ 10$ fine in the Richmond Hustings Court.

\section{IV}

The Supreme Court reversed Boynton's conviction. The Court held, by a margin of seven to two, that section 216(d) of the Interstate Commerce Act barred the discrimination practiced by the terminal restaurant and enforced by Virginia under its trespass statute. But the Court, in the prevailing opmion of Justice Black, achieved this result without reference to the tardily conipiled data bearing on the "intercorporate relationship" of carrier and terminal. "Respondent correctly points out ... that, whatever inay be the facts, the evidence on this record does not show that the bus company owns or actively operates or directly controls the bus terminal or the restaurant in it."

But, in the majority's view, the lack of evidence of control was immaterial:

The protections afforded by the Act against discriminatory transportation services are not so narrowly limited. We liave held that a railroad cannot escape its statutory duty to treat its slippers alike either by use of facilities it does not own or by contractual arrangement with the owner of those facilities. United States v. Baltimore \& Ohio R. Co., [333 U.S. 169 (1948) ] . . . And so liere, without regard to contracts, if the bus carrier has volunteered to make terminal and restaurant facilities and services available to its interstate passengers as a regular part of their transportation, and the terminal and restaurant have acquiesced and cooperated in this undertaking, the terminal and restaurant must perform these services without discriminations prohibited by the Act. In the performance of these services under such conditions the terminal and restaurant stand in the place of the bus company in the performance of its transportation obligations. Cf. Derrington v. Plummer, 240 F.2d 922, 925-926, cert. denied,

Boynton v. Virginia, 81 Sup. Ct. 182 (1960). And in Tucker v. Texas, 326 U.S. 517, 519 n.1 (1946), the Court announced that "we can take judicial notice" of regulations of the Federal Public Housing Authority which had apparently not been introduced at petitioner's trespass trial in the Justice Court of Medina County, Texas.

It hardly need he pointed out that the immediate issue is the Court's capacity to go outside the record for "facts" in the narrowest common-law sense of the term. There of course is little real question of the Court's capacity, and indeed its obligation, to educate itself about the limitless range of economic, historic, philosophic and cultural information which necessarily impinges on great public law cases. See Karst, Legislative Facts in Constitutional Litigation, Sur. CT. REv. 75 (1960); Black, The Lawfulness of the Segregation Decisions, 69 YaLE. L.J. 421, 426-29 (1960).

4281 Sup. Ct. at 186. 
353 U.S. 924. Although the courts below made no findings of fact, we think the evidence in this case shows such a relationship and situation here. ${ }^{43}$

Two points seem im order-one relating to the cases cited by the Court, the second relating to what the Court thought "the evidence in this case shows ....":

\section{As to the Cases}

United States v. Baltimore \& Ohio R.R. grew out of an ICC proceeding against several railroads, including the New York Central, and the Cleveland Union Stock Yards Company. Union Stock Yards owned a 1,619foot segment of a spur line, both ends of which were owned by the New York Central. The spur led from the New York Central's main hine through and past Union Stock Yard's property to a number of private railroad sidings, one of which belonged to Swift \& Company. Union Stock Yards had exacted from the New York Central, and other railroads which used the Central's tracks, an agreement not to use the spur to dehiver livestock to Swift except on payment to Union Stock Yards of fees calculated to be equivalent to those which Union Stock Yards would have collected if livestock consigned to Swift had actually been unloaded and processed at Union Stock Yards. The railroads, therefore, ceased delivering livestock to Swift. The ICC concluded that this was a discrimination against Swift which violated section 3 (1) of the act. A federal district court set the ICC order aside, but the Supreme Court reinstated the order:

We think (said Justice Black for the Court) the provisions of the Interstate Commerce Act plainly empowered the Commission to enter this order against the discriminatory practices found, despite ownership of Track 1619 by Stock Yards. Section 1(1) (a) makes the Interstate Commerce Act applicable to common carriers "wholly by railroad." Section 1(3) (a) defines the term "railroad" as including "all the road in use by any common carrier operating a railroad, whether owned or operated under a contract, agreement, or lease, and also all switches, spurs, tracks ...." .... It is true, as appellees argue, that the above language of $\$ 1(3)$ (a) is definitional only. Ellis v. Interstate Commerce Comm'n, 237 U.S. 434. But it is also true that these definitions by their unambiguous language make all trackage "in use by any common carrier" subject to the regulatory provisions of the Act, even though not owned by the carrier but only used by it under a contract or agreement. Thus Track 1619, though owned by Stock Yards was subject to the Act because of its use by the New York Central under trackage agreements." ${ }^{24}$

Surely there can be no quarrel with Justice Black's conclusion, in United States v. Baltimore \& Ohio R.R., that the portions of the Interstate ConImerce Act which define a "railroad" embraced the discrimination there at 
issue. But it remains a mystery how a holding proscribing a discriminatory arrangement falling within the act's "railroad" definitions is authority for a holding proscribing an arrangement which hypothetically (i.e., excluding from judicial cognizance the documentation of the "intercorporate relationship") fell outside the act's definitions of a motor carrier.

The other case referred to by the Boynton majority was Derrington $v$. Plummer. There, the basement of a Texas county courthouse, "planned, equipped and furnished by the County for use as a cafeteria," "was leased to a private entrepreneur who operated the cafeteria on a "whites only" basis. On fourteenth amendment grounds, the Court of Appeals for the Fifth Circuit properly sustained a decree restraining county officials from permitting continued operation of the leased premises in this fashion:

If the County had rendered such a service directly, it could not be argued that discrimination on account of race would not be violative of the Fourteenth Amendment. The same result inevitably follows when the service is rendered through the instrumentality of a lessee; and in rendering such service the lessee stands in the place of the County. ${ }^{46}$

As the Supreme Court has pointed out in the Little Rock Case, Derrington v. Plummer succinctly illustrated an important constitutional principle: "[T] he prohibitions of the Fourteenth Amendment extend to all action of the State denying equal protection of the laws ... whatever the guise in which it is taken ...." Surely that constitutional teaching is transferable to the less demanding context of the Interstate Commerce Act. In Boynton it would tend strongly to support the argument that the restaurant-lessee's discrimination is not a business practice of which the terminal-lessor can wash its liands. But the relevance of this argument depends upon an antecedent determination that the terminal has a statutory obligation not to discriminate. Such a determination would seem supportable if it is acknowledged that (as Virginia Stage Lines had advised the ICC) the motor carrier controlled the terminal. But the Supreme Court-apparently guided by an elaborate, if unarticulated, deference to the Virginia law of judicial notice -had elected to decide the case on a narrower view of the record: "[W] hatever may be the facts, the evidence in this record does not show that the bus company owns or actively operates or directly controls the bus terminal. ..."

45 Derrington v. Plummer, 240 F.2d 922, 925 (5th Cir. 1957), cert. denied, 353 U.S. 924 (1957).

46240 F.2d at $925-26$. Now awaiting decision in the Supreme Court is a comparable case, Burton v. Wilmington Parking Authority. See 29 U.S.L. WeEk 3253 (U.S. Feb. 28, 1961) (No. 164).

47 Cooper v. Aaron, 358 U.S. 1, 17 (1958).

48 See text at note 42 supra.

It should be observed that, even if the carrier's stock interest in the terminal had been documented at trial, not all courts would have acquiesced in the proposition that this interest constituted "control" in the statutory sense. The point is graphically illustrated by the Ninth 
In short, Derrington would have been extremely compelling precedent if the Court had allowed itself judicially to "notice" and publicly to acknowledge the relevant corporate data with which it was fully acquainted. But without the support of that data, or of some equivalent proof of the carrier-

Circuit's opinion in Spears v. Transcontinental Bus Sys., 226 F.2d 94 (9th Cir. 1955), affirming dismissal of a damage action brought by a Negro passenger who had been ordered by the driver to move to the rear of a Continental Southern Lines bus while on the Mississippi leg of a San Francisco to New Orleans and return bus trip. The plaintiff had purchased his ticket in California from defendant Transcontinental, the corporate parent of Continental Southern, and suit was brought in a federal district court in California against Transcontinental. The court's opinion illuminates an analysis of "control" antithetic to that assumed for the purposes of this essay; also, the court's opinion happens to contain an extended description of the Trailways bus system (a description which can at least be reproduced here, whether or not it may be regarded as a fit subject for judicial notice):

Both Spears and the American Civil Liberties Umon contend that liability should be imposed on Transcontinental because of the direct relationship of parent and subsidiary, and that the parent corporation should be held responsible for acts done by the subsidiary.

Transcontinental Bus System is a member of Continental Trailways, the trade naine of the Trailways organization, an association of about fifty carriers which have banded together into a national bus system. The three operating divisions of Transcontinental Bus System are members of the Trailways association, as are the other bus companies over whose lines Spears traveled en route to New Orleans, including Continental Southern Limes. Transcontinental itself earried Spears only as far as Little Rock, from which point he traveled over the lines of other Continental Trailways associates.

Evidence as to Transcontinental's control over Continental Southern was limited to a showing of complete or nearly complete stock ownership, and thereby participation in the profits of the subsidiary; participation in tariffs issued by the National Bus Tariff Association and filed with and approved by the Interstate Commerce Commission as to the agreed prorated share between the carriers involved as to rates; and various records of the Interstate Commerce Commission. These records show the relationship of Transcontinental to various subsidiaries and affibated companies, including Continental Southern, as summarized by the Commission. They reveal stock ownership by Transcontinental of various companies, and mergers involving appellee. The only relevant sections relate to Transcontinental's willingness to advance funds to Continental Southern required to make advances in the acquisition of another corporation, on open account and without interest; and a warning that appropriate steps should be taken to effect a sinplification of the intercorporate structure of the Transcontinental system at the earbiest possible date.

None of this evidence, however, indicates more than Transcontinental's ownership of its subsidiary. No evidence was submitted showing any direct operating control over the rules, regulations or policies of Continental Southern.

There was, on the other hand, uncontradicted testimony that the only agreements between the two corporations were by participation in the national tariffs and that no other contractual agreements existed between them. There was also testimony that the corporations had separate directorates and were responsible for making and enforcing their own rules and regulations.

Generally, a corporation and its stockholders are deemed separate legal entities and stock ownership in itself is not sufficient to charge the parent company with responsibility for acts of the subsidiary. This rule is subject to the qualification that the separate entities may be disregarded in exceptional situations where it would otherwise present an obstacle to the due protection or enforcement of public or private rights ....

Unfortunate as was the discrimination against Spears, there is no basis on the record as presented to hold Transcontinental responsible for the acts. No facts 
terminal identity, Derrington, like United States v. Baltimore $\mathcal{E}$ Ohio $R$. $R$., falls lifeless to the ground.

2. As to the Facts

Was there equivalent proof in the state record? Seven Justices seemed to think so. Seven Justices stated that

if the bus carrier has volunteered to make terminal and restaurant facilities and services available to its interstate passengers as a regular part of their transportation, and the terminal and restaurant have acquiesced ... . in this undertaking, the terminal and restaurant must perform these services without discriminations prohibited by the Act. ${ }^{40}$

And these seven Justices, viewing the state record, concluded, "[W]e think the evidence in this case shows such a relationship and situation here."

As the seven Justices observed, "the courts below made no findings of fact ...." The Supreme Court of the United States was the first tribunal to attempt any explicit assessment of "the relationship and situation." Here, as in Thompson v. Louisville, the Supreme Court was compelled-by the insufficiency of the judicial process below-to conduct that independent examination of the facts adduced at a state criminal trial which the Court's narrow revisory role ordinarily precludes.

One not clothed with judicial responsibility should be at least as hesitant to quarrel with the Supreme Court's considered findings, in the unusual case in which that tribunal is the only finder of fact, as the Supreme Court is hesitant, in the ordinary case, to overturn the considered findings of a state trial court. This makes it tempting, in Boynton, to concur in the Court's assessment of the "relationship and situation"--that "the bus carrier ... volunteered to make terminal and restaurant facilities ... . available to its interstate passengers as a regular part of their transportation, and the terminal and restaurant have acquiesced ... in this undertaking." temptation to concur in the conclusion that the Trailways bus system was in all things the prime mover is strengthened by the extent to which the state record seems suffused with the immanence of Trailways. There is the fact that Boynton was on a Trailways bus. There is the name of the terminal (but this, by hypothesis, must be cast out of the reckoning). And there

were presented to the trial court showing that Transcontinental had even an awareness of the rules and regulations of Continental Southern. . . .

[R] Jegardless of whether or not a claim against Continental Southern would he valid, there is no proof that Transcontinental operated ot controlled the bus.

Id. at $97-98$.

4081 Sup. Ct. at 186.

50 Ibid.

51 Ibid.

52 Ibid. 
are occasional allusions which make the Trailways system, or a constituent entity thereof, seem a brooding omnipresence:

Q. The bus company has no control over the operation of the restaurant?

A. None whatsoever. ${ }^{53}$

But a moment's attention to the quoted question and answer shows that "the bus company" not only "has no control," it has, so far as the sworn testimony goes, no identity. On one occasion, to be sure, defendant's counsel gave to the felt presence a name:

Q. Your restaurant is primarily or partly for the service of the passengers on the Trailways bus? ${ }^{54}$

But the resultant colloquy dribbled off:

A. For the white on that side, colored on the other.

Q. It is for passengers on the bus, for white passengers?

A. Not necessarily, no. We have quite a bit of business here froin local people..$^{55}$

Beyond what has just been recited, the state record does not connect Virginia Stage Lines or any other element of the Trailways bus system with the bus terminal or with the restaurant it housed. As Justice Whittaker put it, in a dissent in which Justice Clark joined,

There is no evidence of any agreement, express or imphed, between the proprietor of this restaurant and any bus carrier. Instead, the undisputed evidence is that the restaurant was not in any way affiliated with or controlled by any bus carrier. On this evidence, I am unable to find any basis to support a conclusion that this restaurant was in some way inade a facility of the bus carrier, or subject to Part II of the Interstate Commerce Act. ${ }^{56}$

Of course there is evidence-the lease abounds with it - of a joint undertaking by the restaurant and the terminal to maintain dining facitities for bus passengers. But there was no testimony to show that this undertaking was entered into at the instance of Virginia Stage Lines, or any other element of the Trailways system, or that the Trailways system advertised to Boynton or to the public generally the routine availability of the Richmond terminal's restaurant or other facilities or, indeed, that Trailways buses, as the Court seemed to infer, stopped at the Trailways Bus Terminal in Richmond "as a regular part of their transportation." Althougli the seven Justices read the record as showing "that Trailways was not utilizing the terminal and restaurant services ... on a sporadic or occasional basis," ${ }^{57}$ no

53 See note 31 supra.

ธ4 Ibid.

55 Transcript of Record, p. 23, Boynton v. Virginia, 81 Sup. Ct. 182 (1960).

5681 Sup. Ct. at 191.

57 Id. at 187 . 
testimony discloses when last a Trailways bus had stopped, or with what frequency, or when a Trailways bus might be expected to return. As far as the facts of record are concerned, the Trailways bus on which Boynton traveled might as well have been Halley's Comet. Just as the Supreme Court in Thompson v. Louisville could "find no evidence whatever in the record" demonstrating Thompson's guilt, so in Boynton there was no evidence whatever in the record demonstrating the "relationship and situation" found by the Supreme Court. If Bruce Boynton's case had to be decided by applying the Interstate Commerce Act to the facts contained in the state record, his conviction should have been affirmed.

\section{V}

The seven members of the Boynton majority concluded that Virginia's attempt to punish Bruce Boynton for trespass, i.e., for remaiming in the white portion of the restaurant "without authority of law," supreme federal law. "He was there 'under authority of law'-the Interstate Commerce Act-and it was error for the Supreme Court of Virginia to affirm his conviction."

But the najority opinion did not end there. Perhaps sensing that their opinion up to that point "fail[ed] to build the bridge between the authorities ... cite[d] and the results ... decree [d]", "60 the majority Justices felt impelled to go further and "say a word about what we are not deciding." Whatever judicial self-doubts this postscript reflects, it offers some useful insight into what nay really have been uppermost in the nuajority's thinking:

We are not holding that every time a bus stops at a wholly independent roadside restaurant the Interstate Commerce Act requires that restaurant service be supphed in harmony with the provisions of that Act. We decide only this case, on its facts, where circumstances show that the terminal and restaurant operate as an integral part of the bus carrier's transportation service for interstate passengers. Under such circumstances, an interstate passenger need not inquire into documents of title or contractual arrangeinents in order to determine whether he has a right to be served without discrimination. ${ }^{62}$

Enough has been said to indicate that the record to which the Supreme Court felt itself bound was entirely consistent with the possibility that the

58 See text at note 14 supro.

6981 Sup. Ct. at 187.

60 The phrase is taken from Bickel and Wellington, Legislative Purpose and the Judicial Process: The Lincoln Mills Case, 71 Harv. L. Rev. 1, 3 (1957). Professors Bickel and Wellington were talking of the recent spate of per curiam decisions. See note 23 supra.

6181 Sup. Ct. at 188.

62 Ibid. 
restaurant Boynton entered was "wholly independent." Moreover, that record did not "show that the terminal and restaurant operate[d] as an integral part of the bus carrier's transportation service for interstate passengers." If it was really unnecessary for Boynton, in order to enjoy rights under the Interstate Coinmerce Act, to "inquire into documents of title or contractual arrangements," it is hard to avoid the feeling that what saved Boynton that trouble was the Supreme Court's own inquiry after the event.

Perhaps, however, there was more than mere quixotism in the Court's readiness, first, to identify and then to jettison actual facts, and, second, to substitute for those facts a bright gossamer of supposition. Perhaps the Court was not really concerned about the details of Bruce Boynton's personal odyssey. Perhaps, indeed, the Court was not really very interested in minute exegesis of the Interstate Commerce Act or in concepts of corporate control which may have relevance for that act. Possibly the Court's real startmg point was none of these. Perhaps it was the assumption (unsupported on the record to be sure, but apparently a proper subject for judicial notice) which the Court voiced somewhat before its peroration-the assumption that, "Interstate passengers have to eat...." Perhaps the Court's next port of call was the comparably unlitigated assumption that typically the interstate bus passenger eats at a bus terminal rather than "at a wliolly independent roadside restaurant." "Then the Court may liave indulged the further assumption that typically ("wliatever may be the facts" in this particular litigation) "the terminal and restaurant operate as an integral part of the bus carrier's transportation service." If these assumptions about interstate bus travel are reasonably accurate, then it may well follow that the orderly flow of such travel could be seriously impaired by any racially discriminatory practices which, througli segregation or exclusion at bus terminal restaurants, delay or deny access to essential eating facilities and, as a divisive by-product, create or aggravate tensions among the travelling population. Such an inference would certainly seem consistent with the holding in Morgan $v$. Virginia ${ }^{65}$ that racially segregated bus seating, required by state statute, unduly burdens interstate commerce. At all events, the validity of the conclusion that such practices might unduly hamper interstate bus travel would not seem to depend in any degree upon an inquiry - whether conducted by an interstate traveler or by a judge- "into documents of title or contractual arrangements" structuring the "intercorporate relationship" of a specific bus system, bus terminal, and bus terminal restaurant. The Court, in making a judgment about the proper administration of interstate bus travel as a wliole, could regard Boynton's bus as merely

Q3 Id. at 187.

04 Emphasis added.

65328 U.S. 373 (1946). 
a convenient illustration of and vehicle for a more general problem. For when the Court plays this role, the Justices are not confined to the record certified to them by the court below. As in Morgan, the judicial horizon "properly ... . includes facts bearing on interstate motor transportation beyond those immediately involved in this journey under the Virginia statutory regulations."66

But, if the Court was ready to measure Boynton's case in the larger scales of "burden on commerce," why did it not avow this more inclusive rationale? Or, to put the question in another way, if the Court was willing to decide the Morgan case in constitutional terms as long ago as 1946, what made the Court more timid in 1960 ?

The real answer is that in both Morgan and Boynton the Court followed its customary practice of choosing the narrowest ground of decision. The anomaly is that in Morgan the narrowest ground-or at least the ground of most limited implication-was the commerce clause rather than the Interstate Commerce Act. To have decided Morgan on a nonconstitutional basis would have required the Court to reach the conclusion that racial segregation per se was "unjust discrimination or ... undue or unreasonable prejudice," within the meaning of section 216 (d) of the act. Presumably, such a reading of section 216 (d) would have implied a comparable reading of section $3(1)$, the anti-discrimination provision relating to railroads. The ICC, however, had read section 3(1) as sanctioning segregation in an unbroken line of cases running back to volume 1 of the ICC Reports. In 1887, nine years before Plessy v. Ferguson, ${ }^{07}$ the fledgling ICC had read its new charter in terms which bespeak an almost clairvoyant anticipation of the "separate but equal" doctrine:

It is a custom of the railroad companies in the States where the defendant's road is located, and in all the States where the colored population is considerable, to provide separate cars for the exclusive use of colored and of white people.

In Pennslyvania, where, by regulation, separate seats were provided, a colored woman refused to occupy the seat assigned to her; she was put off the train, and the supreme court of the State in that case declared the separation of white and colored passengers in a public conveyance to be a subject of "sound regulation to secure order, promote comfort, preserve peace, and maintain the rights of both carriers and passengers." In a later case in Illinois the supreme court held that public carriers have no right to discriminate between passengers on account of color "until they do furnish separate seats equal in comfort and safety to those furmished to other travelers," the obvious meaning of which is that to furnish separate seats equal in comfort and safety is not unjust discrimmation.

These interpretations of the law are in conformity with the decision of 
Justice Woods, late of the United States Supreme Court, denying to the children of colored parents in Louisiana, under the laws of that State, the right to "attend the same public schools as those in which white children are educated." In this case Justice Woods said "equality of rights does not necessarily imply identity of rights."

The people of the United States, by the votes of their representatives in Congress, support the public schools of the country's capital city, and here white and colored children are educated in separate schools. Congress votes public moneys to separate charities; men, black and white, pitch their tents at the base of Washington's Monument to compete in the arts of war in separate organizations. Trades unions, assembles, and industrial associations maintain and march in separate organizations of white and colored persons.

Public sentiment, wherever the colored population is large, sanctions and requires this separation of races, and this was recognized by counsel representing both complainant and defendant at the hearing. We cannot, therefore, say that there is any undue prejudice or unjust preference in recognizing and acting upon this general sentiment, provided it is done on fair and equal terms. ${ }^{68}$

Thus, for the Supreme Court in 1946 to have decided Morgan on statutory grounds would have involved repudiation of a settled administrative reading of the Interstate Commerce Act which had, for half a century, been virtually interchangeable with the settled Supreme Court reading of the equal protection clause. Judicial departure, in 1946, from the well understood meaning of the act would seem to have signaled imminent judicial departure from the constitutional principle of "separate but equal"-a step which the Court was not to take until eight more long years had passed.

In Boynton, comparable instincts of judicial restraint probably dictated recourse to the Interstate Commerce Act as the least common demominator of decision. To have pitched the case on commerce clause grounds would have forced the Court either to find that the Commonwealth was a partner in the restaurant's restrictive policies, or to determme that state responsibility was an unnecessary ingredient of a "burden on commerce" case. It would not have been unprecedented to decide that privately imposed restraints on the national economy, against which Congress has taken no action, are nonetheless subject to the scrutiny of the Court in its capacity as watchdog of the commerce power. But the precedent principally consists of Justice Brewer's opinion in In re Debs, where the Court, deliberately eschewing reliance on the recently adopted Sherman Act, sustained on general principles the ill-starred injunction which a federal trial court, acting at the behest of the Attorney General of the United States, had handed down to break the paralyzing Pullman strike: "If a State with its recognized powers of sovereignty is impotent to obstruct interstate commerce,

68 Council v. Western \& Atlantic R.R., 1 I.C.C. 638, 641 (1887). 
can it be that any mere voluntary association of individuals within the limits of that State has a power which the State itself does not possess?" ${ }^{00}$ The rhetorical question posed by the Court in 1895 is certainly of sufficient generality to sustain judicial action of the most free-wheeling kind; but Debs, whatever its intrinsic validity on its own facts, was of course distinguishable from Boynton in that Debs was an action brought by the United States to vindicate the national sovereign's unique governmental and proprietary responsibilities. In 1960, apparently, the United States was willing to forego that distinction. At any rate, the United States, as amicus, argued to the Court in Boynton "that racial segregation imposed by a private carrier alone, unsupported by state authority, would also constitute an unlawful burden on interstate commerce." in the view that it has a general warrant to police private impediments to commerce would, of course, have been an enormously far-reaching alteration of the conventionally understood partnership of the Court and Congress. In 1945, writing for the Court in Southern Pacific Co. v. Arizona, Chief Justice Stone put it this way:

For a bundred years it bas been accepted constitutional doctrine that the commerce clause, without the aid of Congressional legislation . . . affords some protection from state legislation inimical to the national commerce, and that in such cases, where Congress has not acted, this Court ... is under the commerce clause the final arbiter of the competing demands of state and national interests. ${ }^{71}$

If some measure of state involvenient remains a necessary ingredient of "burden on commerce" cases, isolating that ingredient in Boynton surely presented no great obstacle. Clearly enough, the obnoxious racial policy of the terminal restaurant depended for its aggravated effect on Virginia's willingness to back it up by enforcement of the trespass statute. But-just as in Morgan reliance on the anti-discrimination provisions of the Interstate Commerce Act would have evoked premature echoes in the field of equal protection-so, in Boynton, judicial readiness to assign Virginia's prosecutorial role constitutional weight in a commerce clause setting would have been widely read as a predefinition of the same quantum of state activ-

60158 U.S. 564,581 (1895).

70 Brief for the United States as Amicus Curiae, p. 11 n.6, Boynton v. Virginia, 81 Sup. Ct. 182 (1960). The United States cited two Court of Appeals decisions-Chance v. Lanibeth, 186 F.2d 879 (4th Cir. 1951) and Whiteside v. Southern Bus Lines, Inc., 177 F.2d 949 (6th Cir. 1949) - and consigned Debs to the category of "cf." A year before Boynton, in a concurring opinion in Steelworkers v. United States, 361 U.S. 39, 61 (1959), Justices Frankfurter and Harlan had occasion to refer approvingly to Debs; but in considerably narrower terms: "Tho crux of the Debs decision, that the Government may invoke judicial power to abate what is in effect a nuisance detrimental to the public interest, has remained intact."

71325 U.S. 761,769 (1945). 
ity as "state action" for fourteenth amendment purposes. In Boynton's own case, the seeming equation would dictate that if Boynton's trespass conviction for staying in the "white" section of the restaurant unduly trammeled the flow of the nation's commerce, so too it deprived Boynton of the equal protection of the laws. And from this, it might appear to follow that the "sit in" tactic is constitutionally protected-i.e., that the fourteenth amendment precludes any merchant from selecting customers on a racial basis and backing up his selection through resort to the police. Moreover, if there is some doubt whether the candy-store proprietor is entitled to have the state enforce his bigotry on his business premises, it is arguable that he is similarly disarmed at home.

Doubtless, the Court in Boynton was fully aware of the ramified implications of a decision based on the commerce clause. Doubtless, this awareness was largely responsible for the fashioning by the majority of a much more awkward rationale.

This explains why the majority roughhewed Boynton's case to fit the procrustean bed of the Interstate Commerce Act. But it does not entirely excuse the process. For, granted the apparent implications of a decision which acknowledged Virgima's role in effectuating the restaurant's restraint on commerce, a moment's reflection suggests that the transferability of the principle to a fourteenth amendment context, and its infimite extension in that context, have not quite the inevitability which has been suggested.

First, there is no reason to assume that the quantum of state authorization, acquiescence or support which brings the commerce clause into play is in all situations mathematically equatable with the quantum of positive state policy which is the target of the explicit mandate, "No State ... shall deny to any person within its jurisdiction the equal protection of the laws." Because this is a Constitution which the Court is expounding, every instinct impels suspicion of such an easy verbal equation.

The point was graphically made in Marsh $v$. Alabama, ${ }^{72}$ where the Supreme Court held that the first amendment liberties enshrined in the fourteenth amendment precluded Alabama's trespass prosecution of a Jehovah's Witness who distributed religious pamphlets on the company-owned streets of the company-owned town of Chickasaw. In the course of his opimion for the Court, Justice Black sought support in situations raising issues which he acknowledged to be

not directly analogous to the [issue] ... before us .... Had the corporation here owned the segment of the four-lane highway which runs parallel to the "business block" and operated the same under a state franchise, doubtless no one would have seriously contended that the corporation's property interest in the highway gave it power to obstruct through traffic 
or to discriminate against interstate commerce. ... And even had there been no express franchise but mere acquiescence by the State in the corporation's use of its property as a segment of the four-lane highway, operation of all the highway, including the segment owned by the corporation, would still have been performance of a public function and discrimination would certainly have been illegal. ${ }^{73}$

Justice Frankfurter, in a concurring opinion, after expressing his continued reservations as to the content the Court had given the first amendment in prior pamphlet cases, noted his agreement that these cases were controlling and his further agreement that the amendment's applicability could not turn on whether the town streets were "private" under Alabama law:

And so I agree with the opinion of the Court, except that portion of it which relies on arguments drawn from the restrictions which the Commerce Clause imposes on State regulation of commerce. It does not seem to me to further Constitutional analysis to seek help for the solution of the delicate problems arising under the First Amendment from the very different order of problems which the Commerce Clause presents. The latter involves an accommodation between National and State powers operating in the same field. Where the First Amendment applies, it is a denial of all governmental power in our Federal system. ${ }^{74}$

In short, it seems sensible to suppose that the realm of "state action" coming within the purview of the commerce clause would frequently be broader than that which falls within the tighter embrace of the fourteenth amendment.

This is not to say that Boynton's conviction did not deprive him of the equal protection of the laws. Far from it. The point is simply that the conclusion is one which must flow from an analysis of the purposes of the equal protection clause, not from the mechanical substitution of results achieved under other provisions of the Constitution. Conversely, however, the Court's exploration of problems of "state action" under the equal protection clause could be enriched by a conscious and systematic cross-fertilization from those commerce clause cases in which the question of state accountability for challenged restraints is at issue. Had Boynton been decided under the commerce clause, in a carefully limited opinion, then bench and bar alike might have gained considerable insight, redeemable in future litigation, into the cognate but not identical fourteenth amendment issues that the Court did not decide.

If the Court had gone further in Boynton, if it had found "state action" sufficient for fourteenth amendment purposes and had decided that Boynton's conviction transgressed the equal protection clause, the Court might have had extreme difficulty in guarding itself against utterances whose ulti-

73 Id. at 506-07.

74 Id. at 511. 
mate implication can today be only dimly foreseen. And this would surely have been regrettable. For the equal protection clause, properly administered, is, like other crucial constitutional provisions, a delicate instrument.

In an equal protection case, the Court lias to make two interrelated inquiries: It has to decide whether the state lias "acted" in a degree sufficient to make constitutional limitations relevant, and it then must consider, with "this hurdle cleared, the ultimate substantive question, whether in the circumstances of this case the action complained of . . . [is] condemned by the Fourteenth Amendnient . . . ."75 It is, of course, arguable that the decision to be made about a trespass conviction for not observing the segregated pattern imposed by the proprietor of a bus terminal restaurant need not have foreclosed-but, indeed, miglit well have illuminated - the adjudication of remoter controversies. As the United States put the matter in its amicus brief,

The Trailways Bus Terminal in Richmond is not comparable to a home or even to a corner grocery store. Though privately owned, it is an interstate facility operated for the benefit of the general pubhic, in relation to which the broad principle of Marsh $v$. Alabama, supra, may properly be apphed. ${ }^{76}$

This introduction of the dimension of "publicness" into the application of the equal protection clause could foreslradow an endless sequence of judicial line-drawings, a sequence in which the drawn line would very likely shift, and shift again, as the structure of the American community changes. But it is, nonetheless, true that the dimension of "publicness"-if the concept can be said to have some measurable content-makes a certain amount of constitutional sense. Its relevance, as Professor Black has so forcefully shown, finds

reinforcement . . . at least as a matter of spirit, in the fourteenth amendment command that Negroes shall be "citizens" of their States. It is hard for me to imagine in what operative sense a man could be a "citizen" without his fellow citizens once in a while having to associate with him. If, for example, his "citizenship" results in his election to the School Board, the white members may (as recently in Houston) put him off to one side of the room, but there is still some impairment of their freedom "not to associate." That freedom, in fact, exists only at home; in public, we have to associate with anybody who has a right to be there. The question of our right not to associate with him is concluded when we decide whether he has a right to be there. ${ }^{77}$

The trouble is that saying this does little to determine, in any particular context, "whether he has a right to be there." Or, (to revert to the argu-

75 Rice v. Sioux City Cemetery, 349 U.S. 70, 72 (1955).

${ }^{76}$ Brief for the United States as Amicus Curiae, p. 26, Boynton v. Virginia, 81 Sup. Ct. 182 (1960)

77 Black, The Lawfulness of the Segregation Decisions, 69 YALE L.J. 421,429 (1960). 
ment advanced by the Umited States), to describe the bus terminal as a "facility operated for the benefit of the general public" would seem to beg the very constitutional questions which are at issue-whether a private entrepreneur can structure his "public" as lie cliooses, and whether he can enlist state aid to enforce his choice. It is conceivable that Boynton might have been a fruitful starting point for these subtle fourteenth amendment inquiries, since it illustrates the problems in a context of maximum community concern. Yet the "state of the art" in this realm of constitutional analysis is still so primitive as to suggest that Boynton would more likely lrave been a very hazardous starting point. At all events it does not appear that there would have been anything gained in tackling Boynton's extremely difficult fourteenth amendment issues if, as has been suggested, the case could have been disposed of on fairly well-trod commerce grounds. And this is especially true where a thoughtful analysis of the commerce issues miglit liave contributed to a subsequent analysis of the harder problems posed under the amendment. ${ }^{78}$

78 The equal protection problems latent in Boynton were presented again to the Court, less than a month after the Boynton decision, in the first wave of petitions for certiorari arising out of the "sit-ins." See Garner v. Louisiana, 29 U.S.L. WeEK 3214 (U.S. Jan. 17, 1961) (Negro college students convicted of disturbing the peace for sitting at a "whites-only" lunch counter in an otherwise integrated Baton Rouge drug store) ; Briscoe v. Louisiana, 29 U.S.L. WEEK 3214 (U.S. Jan. 17, 1961) (Negro college students convicted of disturbing the peace for sitting in the "white" seats of a segregated lunch counter in the Baton Rouge Greyhound Bus Terminal; the students were not bus passengers) ; Hoston v. Louisiana, 29 U.S.L. WEEK 3214 (U.S. Jan. 17, 1961) (same conduct as Briscoe, sutpra, but taking place in Kress departinent store in Baton Rouge). (In these three cases, the writer is of counsel.) Cf. the following itein in the N.Y. Times, January 21, 1961, p. 41:

\section{Trespass Charges $U$ pheld in Sit-Ins}

Raleigh, N.C., Jan. 20 (AP)-The right of a restaurant operator to refuse service to Negroes was upheld by the North Carolina Supreme Court again Friday in cases growing out of last year's lunch-counter sit-in demonstrations.

"The rule is well established," the court said, "that all operator [sic] of a privately owned restaurant, privately operated in a privately owned building, has the right to select the clientele he will serve and to make such selections based on color, race, or white people in company with Negroes, if he so desires."

The court upheld the conviction of seven persons at Durhain on trespassing charges. They were arrested during sit-in demonstrations at the S. H. Kress Company store last May 6.

On March 7, 1961, leaders of the white and Negro commumities in Atlanta reached an agreement under which Atlanta's "sit in" demonstrations and associated boycotts were to be terminated, on the understanding that leading department, variety and drug stores would in the near future abandon their segregated pattern; a factor in the agreement was the anticipated desegregation, next fall, of the eleventh and twelfth grades of Atlanta's public sehools. N.Y. Times, March 8, 1961, p. 1, col.3. On the same day, the disorderly conduct conviction of a group of whites and Negroes arrested while eating together in a Montgomery restaurant was set aside by an Alabaina appellate court (N.Y. Tines, March 8, 1961, p. , col. ):

\section{Mixed Diners Freed in Alabama Appeal}

Montgomery, Ala., March 7 (AP) - The Alabama Court of Appeals set aside today the conviction of a white college professor, a white minister and seven Negroes arrested while dining together in a Montgomery cafe.

AI [sic] three judges joined in ruling that the disorderly-conduct charges against the nine defendants failed to spell out whate [sic] offense, if any, they had committed. 
It has been argued, in the foregoing pages, that the Supreme Court was unwarranted in reversing Bruce Boynton's conviction in reliance on the Interstate Commerce Act, unless the Court was prepared to notice judicially and draw legal inferences from the corporate data not contained in the state court record.

The Supreme Court could, of course, have remanded the case to the Virginia Court of Appeals and requested that court to consider whether the data was noticeable and relevant. But the procedural history of the recent Virginia miscegenation case, Naim v. Naim, suggests that little might have been accomplished via the remand device. ${ }^{79}$ Accordingly, so it is argued above, the Court should have turned to the two constitutional claims whicl had been duly made. The Court could, it is submitted, have properly reversed Boynton's conviction as a burden on commerce. Whether the conviction was likewise a denial of equal protection is an intricate, portentous,

Eleven others, including the college professor's wife and ten of his white students from MacMurray College at Jacksonville, Ill., were acquitted by an all-white jury that convicted the educator, Dr. Richard Nesmith, last May 10. He is dean of inen and head of the Sociology Department at MacMurray.

The white minister, the Rev. R. Edwin King of Boston University, and the seven Montgomery Negro defendants were tried in another court, without a jury, and all were convicted. Like Dr. Nesmith, they were fined $\$ 100$ and costs.

On March 6,1961, the Supreme Court denied certiorari to review the disorderly conduct conviction of Negroes who refused to comply with an order of the Mayor of Tallahassee to move from "white" seats at a lunch counter located in a variety store. Steele v. Tallahassee, 29 U.S.L. WeEK 326 (U.S. Mar. 6, 1961). It is questionable whether petitioners had taken their case to the highest available Florida court.

70 In Naim v. Naim, 350 U.S. 891 (1955), the Court vacated a Virginia judgment, which, on the basis of the Virginia anti-miscegenation statute, annulled a North Carolina marriage; and remanded the case to the Virginia Supreme Court of Appeals so that the case could in turn be routed back to the trial court for amplification of the record with respect to the parties' relationship to Virginia. The Virginia Supreme Court of Appeals held itself powerless to send the case back to the lower court. 197 Va. 734, 90 S.E.2d 849 (1956). Thereafter the Supreme Court concluded that it was powerless to proceed simce the Virginia court's response to the remand left "the case devoid of a properly presented federal question." 350 U.S. 985 (1956). Of course the constitutional problem presented in Naim $v$. Naim is widely thought to be so sensitive as to make hazardous any generalizations hased on this unique history. (Professor Wechsler feels Naine v. Naim was dismissed on "procedural grounds that [he] make[s] bold to say are wholly without basis in the law." Wechsler, Toward Neutral Principles of Constitutional Law, 73 HARv. L. REv. 1, 34 (1959). But this seems an over-harsh appraisal. Arguably one could justify the attempted remand on the theory that, wholly apart from the validity of anti-miscegenation laws as such, there may be due process himits on Virginia's power to annul a marriage celebrated in North Carolina, at least if neither of the parties was domiciled in Virginia. Cf. Alton v. Alton, 207 F.2d 667 (3d Cir.), cert. granted, 347 U.S. 911 (1954), judgment vacated as moot, 347 U.S. 610 (1954). Nor is it so clear that the Court should have felt compelled to address itself to the equal protection problen when its remand order was returned unsatisfied: for the Court to go forward would have been tantamount to a consideration of anti-miscegenation statutes in vaciso, without reference to a particular factual setting in which Virginia's stake in the marital relationship was known and could be weighed against other interests.) 
and ramified constitutional question-a question of such magnitude and profound implication as to have made it virtually imperative that the Court follow Morgan v. Virginia and decide the case on the commerce ground.

However, a decent respect for the integrity of the judicial process requires acknowledgment that Justice Reed's opinion for the Court in Morgan is as nearly unauthoritative as a non-overruled majority opinion of the Supreme Court can be. To begin with, Justices Black, Frankfurter and Douglas are the only members of the Morgan Court who are still sitting. Of these three, only Justice Douglas joined the Morgan opinion without reservation. Justice Frankfurter acquiesced in the opinion, but noted in a concurrence that he did so "chiefly" because he regarded as "controlling"80 the oft-cited decision in Hall v. De Cuir, ${ }^{81}$ in 1878, where the Court overturned on commerce grounds a Louisiana statute forbidding segregation in public conveyances which the Louisiana courts had applied to sustain a damage action brought by an intrastate passenger against the master of a Mississippi riverboat (the Court recognized that Mrs. De Cuir was only going fifteen miles up the river, but stressed the fact that the boat was on an interstate trip and the possibility that the Louisiana courts might have applied the statute in Mrs. De Cuir's behalf even if she had been travelling in foreign commerce, from New Orleans to Liverpool). Moreover, the Morgan opinion was signed by a total of five Justices in all, so that it is only by virtue of Justice Frankfurter's very tepid adherence that the opinion can, charitably, be considered to reflect the views of a majority of the Court. Finally, although Justice Black concurred in the judgment, he filed an opinion succinctly articulating his deep conviction that the Court's asserted power to set aside state laws impinging on commerce is really national legislative power which the Supreme Court exercises only by usurpation:

The Commerce Clause of the Constitution provides that "Congress shall have power ... to regulate commerce ... among the several States." I have believed, and still believe, that this provision means that Congress can regulate commerce and that the courts cannot. But in a series of cases decided in recent years this Court over my protest has held that the Commerce Clause justifies this Court in nullifying state legislation which this Court concludes imposes an "undue burden" on interstate commerce. I think that whether state legislation imposes an "undue burden" on interstate commerce raises pure questions of policy, which the Constitution intended should be resolved by the Congress.

Very recently a majority of this Court reasserted its power to invalidate state laws on the ground that such legislation put an undue burden on commerce. Nippert v. Richmond [327 U.S. 416]; Southern Pacific Co. v. Arizona [325 U.S. 761]. I thought then, and still believe, that in these cases 
the Court was assuming the role of a "super-legislature" in determining matters of governmental policy. Id., at 788, n.4.

But the Court, at least for the present, seems committed to this interpretation of the Commerce Clause. In the Southern Pacific Company case, the Court, as I understand its opinion, found an "undue burden" because a State's requirement for shorter trains increased the cost of railroad operations and thereby delayed interstate commerce and impaired its effciency. In the Nippert case a small tax imposed on a sales solicitor employed by concerns located outside of Virginia was found to be an "undue burden" even though a sohcitor for Virginia concerns engaged in the same business would have been required to pay the same tax.

So long as the Court remains committed to the "undue burden on commerce formula," I must niake decisions under it. The "burden on commerce" imposed by the Virginia law here under consideration seems to me to be of a far more serious nature than those of the Nippert or Southern Pacific Company cases. The Southern Pacific Company opinion, moreover, relied in part on the rule aunounced in Hall v. De Cuir, 95 U.S. 485, which case held that the Commerce Clause prohibits a state from passing laws which require that "on one side of a State line ... passengers, both white and colored, must be permitted to occupy the same cabin, and on the other be kept separate." The Court further said that "uniformity in the regulations by which ... [a carrier] is to be governed from one end to the other of his route is a necessity in his business" and that it was the responsibility of Congress, not the states, to determine "what such regulations shall be." The "undue burden on commerce formula" consequently requires the majority's decision. In view of the Court's present disposition to apply that formula, I acquiesce. ${ }^{82}$

Justice Black's powerful attack on the Court's historic role is one which even he cannot fully subscribe to; for if the Court has no authority to overturn restraints which "burden" interstate commerce, it is hard to know whence the Court gets the power-in whose exercise Justice Black acquiesces-to overturn those restraints which "discriminate against interstate commerce." $" 83$ In both instances, the Court is fashioning a rule where Congress has made none. However, Justice Black's concurrence in Morgan and dissent in Southern Pacific Co. v. Arizona ${ }^{84}$ help powerfully to point up the vacuity of the concepts on which the Court's power has been said to rest-"the implications of the commerce clause itself . . . or the presumed intention of Congress, where Congress has not spoken ...." 85 The "counmerce clause itself" cannot be the decisive touchstone, or else Congress could not, as it has on occasion done, resuscitate and gain subsequent judi-

82328 U.S. $373,386-88$ (1946).

83 Marsh v. Alabama, 326 U.S. 501, 506 (1946). And compare Bibb v. Navajo Freight Lines, 359 U.S. 520, 529 (1959), which the Court, with the assent of Justice Black, characterized as "one of those cases-few in number-where local safety measures that are nondiscriminatory place an unconstitutional burden on interstate commerce."

84325 U.S. 761 (1945).

$85 I d$. at 768. 
cial approval of state restraints which the Court has initially disallowed..$^{80}$ And the equation of congressional silence with congressional "intention" is, as Thomas Reed Powell long ago demonstrated, pure mythology ${ }^{87}$

The valid, if seldom articulated, basis of the Court's power is that ever since Gibbons v. Ogden ${ }^{88}$ the Supreme Court has reviewed specific state programs challenged as impinging upon over-all national policy in those myriad "cases and controversies" which have arisen because Congress had not anticipated-and institutionally could not anticipate-the particular and detailed contingencies in which overlapping state and national authority would generate conflict. The Court, in short, has made national law interstitially, as common-law courts always have. But in this particular role the Court has been acting, when it has acted wisely, not so much as a "super-legislature" to the states, but as an adjunct legislature to-a junior partner of-the Congress. For Congress retains, and has exercised, the power to re-define the national policy the Court declares. ${ }^{80}$

These generalities take on flesh when the Morgan case itself is re-examined. Morgan, as Justice Frankfurter and Justice Black each observed from their very different perspectives, was thought to follow from the fatuous ruling in Hall v. De Cuir, setting aside Louisiana's reconstructionera attempt to forbid segregated transportation. ${ }^{90}$ But Justice Burton, who

88 Compare Pennsylvania v. Wheeling \& Belmont Bridge Co., 54 U.S. (13 How.) 518 (1851), with Pennsylvania v. Wheeling \& Belmont Bridge Co., 59 U.S. (18 How.) 421 (1855); and compare Leisy v. Hardin, 135 U.S. 100 (1890), with In re Rahrer, 140 U.S. 545 (1891). See also Prudential Ins. Co. v. Benjamin, 328 U.S. 408 (1946).

87 Powell, The Still Small Voice of the Commerce Clause, in 3 Serected Essays on ConSTITUTIONAL LAW 931 (Merrill ed. 1938).

8822 U.S. (9 Wheat.) 1 (1824).

${ }^{89}$ See note 86 supra.

90 The term "fatuous" is used advisedly. Consider the following decisive paragraph of Chief Justice Waite's opinion for the Court (95 U.S. at 490):

This power of regulation may be exercised without legislation as well as with it. By refraining from action, Congress, in effect, adopts as its own regulations those which the common law or the civil law, where that prevails, has provided for the government of such business, and those which the States, in the regulation of their domestic concerns, have established affecting commerce, but not regulating it within the meaning of the Constitution. In fact, congressional legislation is only necessary to cure defects in existing laws, as they are discovered, and to adopt such laws to new developments of trade. As was said hy Mr. Justice Field, speaking for the court in Welton v. The State of Missouri, 91 U.S. 282, "inaction [hy Congress] ... is equivalent to a declaration that inter-state commerce shall remain free and untrammelled." Applying that principle to the circumstances of this case, congressional inaction left Benson at liberty to adopt such reasonable rules and regulations for the disposition of passengers upon his boat, while pursuing her voyage within Louisiana or without, as seemed to him most for the interest of all concerned. The statute under which this suit is brought, as construed by the State court, seeks to take away from him that power so long as he is within Louisiana; and while recognizing to the fullest extent the principle which sustains a statute, unless its unconstitutionality is clearly established, we think this statute, to the extent that it requires those engaged in the transportation of passengers among the States 
dissented in Morgan because so few facts had been adduced to prove the "burden" imposed by the Virginia segregation statute, ${ }^{91}$ added the disturbing observation that the Court's logic seemed to imperil the many northern state laws forbidding racial discrimination in public transportation. And

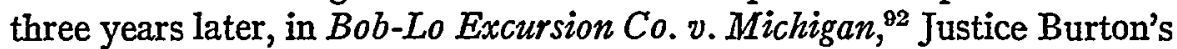
warning came home to roost. For there the Court was confronted with a Michigan statute requiring "full and equal accommodations, advantages, facilities and privileges of ... public conveyances on land and water...."93 The statute had been applied to support the imposition of a fine upon a

to carry colored passengers in Louisiana in the same cabin with whites, is unconstitutional and void. If the public good requires such legislation, it must come from Congress and not from the States.

The quoted paragraph first equates Congressional inaction with adoption of local laws affecting commerce, which for a moment sounds propitious for the Louisiana statute. Then follows a sentence which begins "As was said ...." and which the reader is entitled to expect will reemphasize the doctrine just announced. But, without apparent awareness, the Court actually shifts direction completely at this point and veers off to Justice Field's equation of congressional inaction with "a declaration that inter-state commerce shall remain free and untrammeled." Next, "[a]pplying that principle to the circumstances of this case," the Court determines that Congressional inaction precluded Louisiana's traminels but endorsed the trammels imposed by Benson in his capacity as private legislator "for the interest of all concerned." Finally, after holding the Louisiana statute "unconstitutional and void," the Court advises its audience that "[i]f the public good requires such legislation, it must come from Congress and not from the States." This utterance, taken together with the holding, suggests total judicial unawareness of relevant provisions of the Civil Rigbts Act of 1875: 18 Stat. 335, Section 1 declared: "That all persons within the jurisdiction of the United States shall be entitled to the full and equal enjoyment of the accommodations, advantages, facilities and privileges of inns, public conveyances on land or water, theatres, and other places of amusement; subject only to the conditions and himitations established by law, and applicable alike to citizens of every race and color, regardless of any previous condition of servitude." Section 2 made violation of section 1 a misdemeanor, and created a federal civil cause of action in favor of those subjected to discrimination. In addition, it saved to civil suitors an election "to ... proceed under their rigbts at common law and by State statutes...." The Civil Rights Act was not on the books when Mrs. De Cuir took passage on Captain Benson's river boat; but it had been part of "the supreme law of the land" for nearly three ycars when Hall v. De Cuir was decided by the Supreme Court in 1878. A due awareness of the existence of the federal statute might have discouraged the Court from making a declaration of the present imvalidity of the Louisiana statute in 1878; and it even might have militated against the conclusion that, prior to 1875, the "inaction" of the Reconstruction Congress could be read as demonstrating that Congress preferred any regulation Captain Benson might prescribe to a state statute requiring nondiscrimmation.

Five years after Hall v. De Cuir, the Court, in the Civil Rights Cases, 109 U.S. 3 (1883), dismantled most of the 1875 Civil Rights Act, as going beyond the thirteenth and fourteenth amendinents. But the Court did not address itself to the validity of the provision governing "public conveyances on land or water" because of its curious conclusion that "whether Congress, in the exercise of its power to regulate commerce amongst the several States, might or might not pass a law regulating rights in public conveyances passing from one State to another, is also a question which is not now before us, as the sections in question are not conceived in any such view." 109 U.S. at 19. See 2 Freund, SutherLand, Howe \& Brown, Constitutional Law 803 (1954). Much later, the Court was to determine, on non-separability grounds, that the decision in the Civil Rights Cases also spelled the demise of section 1 of the 1875 act (and of the rights and offenses declared in section 2) in those places such as the District of Columbia, the Territories, and American ships at sea, which are under plenary national control. Butts v. Merchants Transp. Co., 230 U.S. 126 (1913).

81328 U.S. 373,389 (1946).

82333 U.S. 28 (1948).

93333 U.S. 28, 32 (1948). 
ferry company which had refused to carry a Negro girl on an excursion trip from Detroit to an island lying near the mouth of the Detroit Riveran island which is Canadian territory. Hall v. De Cuir had returned in aggravated form. But the Supreme Court affirmed the criminal conviction. The Court, speaking through Justice Rutledge, strove mightily to show the remoteness of conflict between Michigan's interest and any possible Canadian, or United States-Canadian, stake in the controversy. Yet what was ultimately dispositive was the Court's view that Michigan's policy coincided with the public policy of the United States:

It is difficult to imagine what national interest or policy, whether of securing uniformity in regulating commerce affecting relations with foreign nations or otherwise, could reasonably be found to be adversely affected by applying Michigan's statute to these facts or to outweigl her interest in doing so. Certainly there is no national interest which overrides the interest of Michigan to forbid the type of discrimination practiced liere. And, in view of these facts, the ruling would be strange indeed, to come from this Court, that Michigan could not apply her long-settled policy against racial and creedal discrimination to this segment of foreign commerce, so peculiarly and almost exclusively affecting her people and institutions. ${ }^{94}$

It is the public economic policy of the United States which the Supreme Court was authorized, in Boynton, to weigh against Virginia's asserted interest in the enforcement of its trespass statute. That public economic policy dictates that the flow of persons in transit throughout the nation should not be trammeled by state-supported racial restrictions. It is a policy which takes shape from the cognate, if hypothetically non-dispositive, provisions of the Interstate Commerce Act; from the cognate, and perhaps separately dispositive, provisions of the fourteenth amendment; and, indeed, from those remnants of the 1866 and 1870 Civil Rights Acts which gnaranteed Bruce Boynton, as he entered the terminal restaurant in Richmond, "the saine right . . . as is enjoyed by white citizens . . . to . . purchase ... personal property" and "to make and enforce contracts." ${ }^{\circ 5}$ And

04 Id. at 40 .

0514 Stat. 27 (1866), 42 U.S.C. \$ 1982 (1958); 16 Stat.144 (1870), 42 U.S.C. § 1981 (1958).

In its amicus brief in Boynton, the United States seemed at one point (p. 27) to regard these statutes as providing independent support for reversal of Boynton's conviction. But a page later the United States put the matter this way: "When a state abets or sanctions discrimination against a colored citizen who seeks to patronize a busimess establishment open to the general public, the colored citizen is thereby denied the right 'to make and enforce contracts' and 'to purchase personal property' guaranteed by 42 U.S.C. 1981 and 1982 against deprivation on racial grounds." P. 28. So phrased, this statutory argument seems to add nothing to the inhibitions on state-supported discrimination drawn from the fourteenth amendment standing alone. Of course the statutes were enacted in conjuuetion with the framing and adoption of the thirteenth and fourteenth amendinents and descend to present generations presumptively laden with the "state action" requirement insisted on in the Civil Rights Cases, 109 U.S. 3 (1883). Yet if the statutes could be regarded as expressions of national economic policy, implementing 
beyond these specific legislative evidences, it is a policy drawn from every fiber of the nation's heritage. For the Court to find that pohicy and conclude that it outweighed Virginia's stake in the matter should not have been difficult in this instance; it may well be harder in other instances. But the process is a familiar aspect of constitutional adjudication. And the institutional role of the Suprene Court, in declaring national policy in partnership with Congress, in an authentic product of the nation's constitutional development.

\section{CONCLUSTON}

The Warren Court is now rounding out its eighth judicial term. In that span, the Court has, for the most part, policed the federal system with signal wisdom, vigor and responsibility. And, starting with the School Segregation Cases, this has been most true in the realn of racial equality. There the Warren Court has firmly insisted that the United States keep faith with the democratic commitment inscribed in its fundamental documents and given meaning by its almost two centuries of history as an independent nation.

Boynton v. Virginia has been closely canvassed in these pages precisely because, in modest terms, it reflects the major issues of accommodation of national and state authority which have confronted the Warren Court. Moreover, Boynton illustrates the variety of judicial devices available to the Court in approaching the tasks of acconmodation. And the case may shed light on the considerations which should impel the selection of one device in one context, and of another in another.

It has been argned in this essay that the Court should, if possible, have disposed of Boynton on the most himited statutory ground advanced. And

Congressional power over commerce, insistence on "state action" as a necessary ingredient of the Congressional target would be obviated. But this approach would pose two additional problems:

First, whether the Court today would be willing to use the commerce power to sustain legislation plainly predicated on the post-Civil War amendments: this the Court, in the Civil Rights Cases, declined to do with respect to that portion of the Civil Rights Act of 1875 which proscribed discrimination on "public conveyances on land or water"-an inhibition on private action which, with respect to interstate carriers, was plaimly supportable under the commerce power. See note 90 supra. Second, whether the Court, even if ready to look to the commerce power, would be ready to read into the statutes coverage of a range of economic activity (purchasing a meal at a terminal restaurant) which was probably regarded as well beyond the national commerce power at the time these laws were enacted. $C f$. United States v. SouthEastern Underwriters, 322 U.S. 533 (1944).

But if the suggested inquiry is reversed, the argument for giving the statutes independent weight can be made more persuasive. First: Congrss clearly intended to reacb private discrimination of this character. Second: that congressional intention can and therefore should today be vindicated by judicial resort to the commerce power, whatever powers Congress may have thougbt it was exercising at the time. 
a responsible statutory disposition would have been possible, if the Court had elected to acknowledge and utilize relevant facts tardily brought to its attention. There were obstacles to judicial acceptance of those facts-obstacles rooted in the delicacy of the Court's relationship to the inferior but separate judiciaries of the several states. But those obstacles would seem to have been smaller than the logical difficulties presented by deciding Boynton on statutory grounds without the support of the necessary and available facts. Ignoring logical difficulties may obscure but does not dissipate them. And this matters, because, to the extent that the Court expounds a rationale which is unpersuasive, the Court robs itself of some measure of the philosophic and intellectual authority which is in the last analysis the only sure foundation of its supremacy. The statutory analysis advanced in Boynton was not compelling: the Court should have built the analysis on real facts -or should have turned to the Constitution.

There are instances in which it is the sounder part of judicial discretion to blaze a tortuous statutory path than to add constitutional pavement to a broad doctrinal highway stretching towards a limitless horizon. In Boynton, however, the Court confronted a different choice. Apparently hoist on its own self-imposed evidentiary ground rules, the Court could still have adopted a supportable and circumscribable commerce clause rationale, or a hazardous and far-reaching equal protection rationale-or a statutory rationale which simply would not wash. Granted all its ground rules, the Court should have elected the first option; instead, it elected the last.

Doubtless, characterizing the possible commerce clause ground as substantially narrower than the possible fourteenth amendment ground may be regarded as inconsistent with the suggested defense of "burden on commerce" cases as cases really built on a judicial estimate of national policy. This is a proposed analysis which may sound in some ears like a new trumpet call to judicial supremacy. It may be thought to open up (or reopen) the commerce field to the very dangers which Justice Black has perceived in the prevailing Palko interpretation of the fourteenth amendment's due process clause-an accordion-like Constitution whose substance depends on transient, personal, judicial whim. ${ }^{86}$

96 In Palko v. Connecticut, 302 U.S. 319, 325 (1937), Justice Cardozo (speaking for eight Justices, including Justice Black) characterized the rights protected by the due process clause as those "found to be implicit in the concept of ordered bberty. ..." In Adamson v. California, 332 U.S. 46 (1947), the Court reaffirmed Palko and its antecedent, Twining v. New Jersey, 211 U.S. 78 (1908). In dissent, Justice Black, arguing for blanket incorporation of the Bill of Rights into the fourteenth amendinent, took Twining as his target, and asserted that it had fathered a " 'natural law' formula ... [which] should be abandoned as an incongruous excrescence on our Constitution. I believe that formula to be itself a violation of our Constitution, in that it subtly conveys to courts, at the expense of legislatures, ultimate power over public policies in fields where no specific provision of the Constitution limits legislative power." 332 U.S. at 75 . 
The closing paragraphs of this essay on Boynton are surely not the place to pursue Palko, Adamson v. California, ${ }^{97}$ and the continuing debate those cases have rekindled over the relationship between, and the Court's role in administering, the Bill of Rights and the fourteenth amendment. It is the Court's administration of the commerce clause which is in immediate focus. For this reason it should be sufficient, for present purposes, to insist upon the fundamental difference between the binding judicial vetoes on state policy iniposed under the fourteenth amendment and the provisional vetoes imposed under the commerce clause. The latter are subject to legislative revision whenever Congress takes a different view of where the balance of national advantage lies. ${ }^{98}$

Finally, it has been argued above that candid acknowledgment of the Court's responsibility to declare national policy in commerce clause cases would bring constitutional doctrine into harmony with what the Court has in fact done since John Marshall's time. Reference to Gibbons v. Ogden ${ }^{90}$ as a prime example of the authenticity of the Court's role may trouble those who recall that the New York law erecting the great steamboat monopoly was actually held to conflict with the ship-licensing provisions of a particular federal statute. But in retrospect Marshall's anti-climactic and wholly unpersuasive reliance on the federal statute has tended to disappear fron view. The verdict of constitutional history has been that Justice Johnson was correct in his concurring view "that if the licensing act was repealed toniorrow, the rights of the appellant to a reversal of the decision complained of, would be as strong as it is under this license." 100

In Gibbons the question Marshall should have resolved (and which, in essence, he has since been read as having resolved) was whether a statesupported restraint on the national economy, of a kind to which Congress had not as yet specifically addressed itself, was compatible with the best estimate of the needs of the national economy which the Court itself could make. In Boynton, once it had insulated itself from the facts which would have authenticated a statutory rationale, the Court should have resolved the same question.

To put the question with this generality may also serve to clear away, or at least reduce to inanageable proportions, much of the conceptual debris which has begun to accumulate in alarming fashion in cases in which the stated issue is whether, in the absence of an express legislative mandate, Congress has "occupied" or "pre-enupted" the "field."

There is a small nucleus of instances in which Congress has fairly ex- 
plicitly decreed immunity from local encumbrances. Such, for example, was the situation when Congress provided that railways and railway brotherhoods nuay enter into union security agreements without regard for contrary provisions of local law. As the Court made plain in Railreay Employes $v$. Hanson, ${ }^{101}$ the explicit congressional inandate limited the effective range of Nebraska's right to work law.

Then there is a far larger group of instances in which, although Congress has laid down no immediately controlling rule of conduct, effective implementation of a clear-cut congressional mandate logically seems to require freedom from local policies. Such was the situation when Congress, through the "equal time" provision, required radio and television stations which broadcast addresses by political candidates to accord rivals a right of uncensored reply. It would have mocked the congressional purpose if the Court, in Farmers Union v. WDAY, had allowed broadcasting stations to be subjected to defamation suits growing out of the speeches made on "equal time." 102

At the periphery are the hardest cases-those in which state restraints are addressed to a field of federal interest in which Congress may have acted only very remotely or, depending on how the "field" is defined, not at all. Here the chance for judicial error is greatest-as when, for example, the Court, in Nere York Central R.R. v. Winfield, ${ }^{103}$ found in the enactment of the Federal Employers' Liability Act a basis for barring the application of state workmen's compensation laws to railroad employees. But the Court can also be right-as it was, to take a non-commerce case, when, in Pennsylvania v. Nelson, ${ }^{104}$ Chief Justice Warren sustained the Pennsylvania Supreme Court in barring the conviction, under Pennsylvania's anti-sedition laws, of one accused of sedition against the United States. Putting aside the knownothings who have read Nelson as aid and comfort to communism, ${ }^{105}$ the criticisin of $\mathrm{Nelson}$ has mainly come from those who have confined their attention to the Court's inquiry into congressional "purpose" in the Smith Act and related legislation. If Nelson is treated as an attempt to deternnine how best to serve the dominant national interest in a field in which Congress has not spoken with any clarity, the propriety of Nelson becomes clear. And the fact that Congress has not yet "overruled" the Court is some evidence that the Chief Justice and his colleagues of the Nelson majority did not go astray in their assessment of the national interest.

101351 U.S. 225 (1956).

102360 U.S. 525 (1960). The ruling does not, of course, bar suits against the defamers.

103244 U.S. 147 (1917).

104350 U.S. 497 (1956).

105 See, e.g., Amertcan Bar Ass's. Report of the Speciad Committee on Comanunist TACTICS, STRATEGY AND OBJECTIVEs (1959) (a report which the ABA itself neither approved nor disapproved). 
The reason for this résumé of Hanson, Farmers Union, Winfield and $N e l s o n$ is to suggest that they are points along a single federal judicial spectrum, rather than isolated examples of discrepant federal judicial responsibilities. Collectively, they illustrate a single problem: In an area of dominant national responsibility, has Congress explicitly or by necessary implication measured the permissibility of a state restraint? If not, are there other relevant indices-whether legislative, constitutional, historic, economic, cultural, or philosophic - of a national interest which should take precedence over the challenged restraint? Boynton-wholly apart from its latent equal protection issues-exemplifies that problem and the coherent, mutually complementary, judicial approaches to its solution.

$$
\text { ****** }
$$

In the discharge of its revisory authority over the courts of the several states, the Supreme Court has always been a center of controversy. If this were not so, it would only be because the Court had abdicated from its high responsibilities. It is with this in mind that one may ponder an especially forceful indictment of the Supreme Court, voiced by a distinguislied member of its bar-an indictment which seems to gain power from the quaint, if eloquent, deference in which it is framed:

The states are a bundle of arrows easily separated. The union has always broken, and will always continue to break down state oppositions in detail. ... Surely, however, the constitution good as it is, must contain within itself, some principle of decay and mortality. It is not to be found in the capacity of the states to control and overpower the general government; but is there no danger, that the causes of decay and death may exist in the capacity for the very opposite state of things? Enlightened men have thought so, and have viewed the progress of the union towards consolidation with fearful solicitude. . . . For my own part, I have no hesitation in saying, that if the liberties of this country are to be long preserved, it must be done by upholding the rights of the states, and with the utmost respect $I$ say it, if some of the principles laid down by the [C] hief Justice ... are not overruled within twenty years, the constitution will before then have verged towards a form of government, which many good men dread, and which assuredly the people never chose. ${ }^{106}$

The decision under attack is not Pennsylvania v. Nelson, nor even the School Segregation Cases. Indeed, the Chief Justice referred to is not Earl Warren. The Chief Justice is John Marshall, and the decision is Gibbons ข. Ogden.

106 The indictment of Marshall's decision was uttered by Thomas Emmet, one of the losing counsel in Gibbons v. Ogden, in the course of argument before Chancellor Kent in an immediately subsequent case which turned out to be the steamboat monopolists' last unsuccessful gasp. North River Steam Boat Co. v. Livingston, 1 Hopk. (N.Y.Ch.) 149, 189 (1824). See I CROSSkex, Pormitics AND the Constrtution 268-80 (1953). 